\title{
21. Yüzyıl Becerileri Açısından MEB Okul Öncesi Eğitim Programına Eleștirel Bir Bakış*
}

\author{
Mustafa ÇETiN'1, Güler ÇETiN²
}

\begin{abstract}
Öz: Bu araştırmanın amacı, MEB 2013 okul öncesi eğitim programı ve etkinlik kitabının 21. yüzyıl becerileri açısından eleştirel olarak incelenmesidir. Araştırmada doküman analiz yönteminden hareketle, MEB 2013 okul öncesi eğitimi programı ile programın uygulanmasına rehberlik eden etkinlik kitabı, 21. Yüzyıl Becerileri Erken Öğrenme Çerçevesi kapsamındaki öğrenme ve yenilik becerileri, yaşam ve kariyer becerileri ile bilgi, medya ve teknoloji becerileri temel alınarak incelenmiştir. Dokümanlardan elde edilen verilerin incelenmesinde betimsel analiz kullanılmıştır. Araştırmadan elde edilen bulgular, okul öncesi eğitim programı ve etkinlik kitabının öğrenme ve yenilik becerileri ile yaşam ve kariyer becerilerini büyük oranda destekler nitelikte olduğunu göstermiş̧tir. Diğer yandan, araştırmanın bulguları, okul öncesi eğitim programı ve etkinlik kitabında bilgi, medya ve teknoloji becerilerinin ele alınmadığını ortaya koymuştur. Araştırmadan elde edilen bulgular doğrultusunda, okul öncesi eğitim programı ve etkinlik kitabının erken çocukluk döneminde 21. yüzyıl becerilerinin kazandırılmasına yönelik önemli bir potansiyel taşıdığı görülmüştür.
\end{abstract}

Anahtar Sözcükler: Okul Öncesi Eğitimi, Eğitim Programı, 21. Yüzyıl Becerileri, P21

\section{A Critical Outlook on MoNE Early Childhood Education Curriculum in terms of 21st Century Skills}

\begin{abstract}
This study aims to critically examine the salience of 21st century skills in MoNE 2013 early childhood education curriculum (curriculum booklet and activity book). In the study, document analysis, a form of qualitative research, was adopted. MoNE 2013 early childhood education curriculum was systematically examined based on learning and innovation skills, life and career skills, and information, media, and technology skills in 21st Century Skills Early Learning Framework. Descriptive analysis was used to examine and organize the data contained in the documents. The results of the study showed that the curriculum booklet and activity book provided acknowledgement and support for learning and innovation skills and life and career skills. On the other hand, the results of the study revealed that information, media, and technology skills were not addressed in the curriculum booklet and activity book. Clearly, MoNE 2013 early childhood curriculum had the potential to support the implementation of 21st century skills for early childhood.
\end{abstract}

Keywords: Early Childhood Education, Curriculum, 21st Century Skills, P21

* Bu araştırma, 28-22 Nisan 2018 tarihlerinde Antalya'da düzenlenen 27th International Conference on Educational Sciences (ICES 2018) adlı bilimsel toplantıda sözlü bildiri olarak sunulmuştur.

${ }^{1}$ Akdeniz Üniversitesi, Eğitim Fakültesi, Temel Eğitim Bölümü, Antalya, Türkiye, e-posta: mustafacetin@akdeniz.edu.tr, ORCID: https://orcid.org/00000002-4461-5969

2 Bolu Abant İzzet Baysal Üniversitesi, Eğitim Fakültesi, Eğitim Bilimleri Bölümü, Bolu, Türkiye, e-posta: gulerduman@ibu.edu.tr, ORCID: https://orcid.org/0000-0003-3046-3017 
Küreselleşme, uluslararası ekonomik, çevresel ve politik zorluklar, bilgi ve iletişim teknolojilerindeki hızlı değişimler ve gelişmeler, bireylerin başarı için ihtiyaç duydukları bilgi ve becerileri de sürekli olarak değiştirmektedir (Chu, Reynolds, Tavares, Notari ve Lee, 2017; Griffin, Care ve McGaw, 2012; Saavedra ve Opfer, 2012a; Zajda, 2015). Bu nedenle, yalnızca okuma, yazma ve aritmetik becerileri gibi geleneksel temel becerileri edinmek 21. yüzyılda yeterli olmamaktadır. Bu tür becerilerin yanı sıra, Castells (2010) tarafından yoğun bir dönüşüm dönemi olarak tanımlanan 21. yüzyılda başarılı bir işe, vatandaşlığa ve yaşama sahip olabilmek için bireyler, karmaşık problemlere alternatif çözümler üretme, etkili iletişim kurma, yeni bilgiyi üretme ve yönetme, takım olarak çalışma ve hızlı değişime uyum sağlayacak kadar esnek olma gibi becerilere ihtiyaç duymaktadır (Ananiadou ve Claro, 2009; P21-A Network of Battelle for Kids, 2019a). Bu beceriler, genellikle 21. yüzyıl becerileri veya yeterlilikleri olarak adlandırılmaktadır.

Genel olarak, 21. yüzyıl becerileri, bireylerin bilgi toplumuna katkı sağlayabilmeleri için ihtiyaç duydukları bilgi, beceri, kişilik ve zihin özelliklerini içeren kapsayıcı bir kavram olarak ifade edilebilir (Voogt ve Roblin, 2010). Diğer bir ifadeyle, 21. yüzyıl becerileri, dört temel kategoride ele alınabilecek beceriler olarak düşünülebilir (Binkley ve diğerleri, 2012):

- Düşünme Yolları: Yaratıcılık ve yenilikçilik, eleştirel düşünme, problem çözme, karar verme ve öğrenmeyi öğrenme, üst biliş

- Çalışma Yolları: İletişim ve iş birliği (ekip çalışması)

- Çalışma Araçları: Bilgi okuryazarlığı ve bilgi-iletişim teknolojisi okuryazarlığı

- Dünyada Yaşam: Yerel ve küresel vatandaşlık, yaşam ve kariyer, kültürel farkındalık ve yeterlilik, kişisel ve sosyal sorumluluk.

21. yüzyıl becerileri, bireylerin sahip oldukları bilgi birikimlerinden ziyade, bilgiyle neler yapabilecekleriyle ilgilidir (Silva, 2009). Başka bir deyişle, bu tür beceriler özünde, bireylerin eğitim sürecinde gördükleri temel alanlardaki konulara (örneğin, matematik, fen bilimleri, sosyal bilimler vb.) işlevsellik kazandırmada kullandıkları beceriler bütünüdür. Bu doğrultuda, Voogt ve Roblin (2012), 21. yüzyıl becerilerinin üç temel özelliği olduğunu ifade etmektedir. Bunlar; bu becerilerin, (i) belirli bir alanla doğrudan bağlantılı olmayıp, birçok alanla ilgili olması, (ii) bilgi, beceri ve tutumları içeren çok boyutlu bir yapı sergilemesi ve (iii) karmaşık problemler ve öngörülemeyen durumlarla başa çıkmayı sağlayan üst düzey becerilerle ilişkili olmasıdır.

21. yüzyıl becerileri, içinde bulunduğumuz yüzyılda bilgiye dayalı ekonomilerin ortaya çıkan talepleri nedeniyle önemi ve gerekliliği yeniden vurgulanan becerilerdir (Levy ve Murname, 2004; Rotherham ve Willingham, 2009). Daha açık bir ifadeyle, söz konusu becerilerden bazıları yeni ortaya çıkmış beceriler olmayıp, yeniden önemli hale gelmiş becerilerdir (Silva, 2009). Örneğin, eleştirel düşünme ve problem çözme gibi hayati beceriler, ilkel araçların geliştirilmesinden, tarımsal ilerlemelere; aşıların bulunmasından, kara ve denizlerle ilgili keşiflere kadar tarih boyunca insanlığın ilerlemesinde her zaman çok önemli olmuştur (Rotherham ve Willingham, 2009). Nitekim öğrenme ve yenilik becerilerine duyulan bu ihtiyaç, "ilk profesyonel öğretmenler" olarak nitelendirilen Sokrates ve Sofistlere kadar uzanmaktadır (Johnson ve Reed 2008, s. 23). Bununla birlikte, mevcut bilgi çağına özgü bazı becerilerin bulunduğu da unutulmamalıdır. Örneğin, teknolojinin evrimine ayak uydurabilmek için bireylerin yaşam boyu öğrenenler olma gerekliliğini kabullenmeleri önemlidir (Medel-Añonuevo, Ohsako ve Mauch, 2001). Dolayısıla, "21. yüzyıl becerileri" terimi kulağa modern gelse de, bu becerilerin birçoğu yeni olmamakla birlikte günümüzde dört nedenden ötürü yeniden önem kazanmıştır.

Birincisi, PISA, TIMSS gibi uluslararası sınavlarda fen, matematik ve okuma becerileri alanlarından alınan düşük puanlar, öğrencilerin okullarda kazandıkları temel bilgileri gerçek yaşam durumlarına uyarlamada zorluk yaşadıklarını göstermektedir (Martin, Mullis, Foy ve Hooper, 2016; Mullis, Martin, Foy ve Hooper, 2016; Suna, Tanberkan ve Özer, 2020). Bu durum, 21. yüzyılda tüm bireylerin hayata hazır olmaları için sahip olmaları gereken temel becerileri kazanamadıklarına işaret etmektedir. Dolayısıyla, uluslararası sınavların bilgiyi değil yetkinlik ve becerileri ölçmeye dayanan yapısı, ülkelerin hem eğitim politikalarının önceliğinin belirlenmesinde hem de eğitim programlarının 21. yüzyıl becerilerini kapsayacak şekilde güncelleme 
çalışmalarının yapılmasında etkili olmaktadır (Schleicher, 2019). İkincisi, ekonominin küreselleşmesiyle birlikte bilgi ve iletişim teknolojilerinin hızlı gelişimi, çalışma biçimlerini de sürekli olarak değiştirmektedir. Bilgi toplumu olarak tanımlanan günümüz toplumunda, birçok işin önemli bir kısmı artık yalnızca bilgi alışverişiyle değil, aynı zamanda belirli bir bilgi anlayışıyla ve üretimiyle de ilgilidir (Levy ve Murnane, 2004). Dolayısıyla, bilgi toplumunun talep ettiği iş türlerindeki dinamik değişiklikler, işyerlerinde karmaşık sorunları çözmek için etkili iletişim kurma, bilgiyi yaratma, kullanma ve paylaşma, yeni taleplere ve değişen koşullara uyum sağlama, yeniliklere açık olma gibi becerilere önem verilmesine yol açmıştır (Binkley ve diğerleri, 2010; Saavedra ve Opfer, 2012b). Bunun yanı sıra, küresel pazardaki arz ve talep, bireylerden henüz var olmayan geleceğin mesleklerine hazırlanmalarını için birtakım becerileri kazanmalarını istemektedir (Dede, 2011). Bu beceriler, daha çok iş birliği gerektiren disiplinler arası özellikteki iş kollarında, uyumlu çalışma, esneklik, üretkenlik gibi 21. yüzyıl becerilerine işaret etmektedir (Saavedra ve Opfer, 2012b).

Üçüncüsü, bireylerin 21. yüzyıl becerilerini kazanmaları için güçlü bir yurttaşlık gerekçesi de bulunmaktadır. 21. yüzyıl becerileri, dünya vatandaşı olarak yalnızca ulusal düzeyde değil, aynı zamanda küresel anlamda sağlıklı bir topluma katkı sağlayabilmek için hak ve sorumluluklarının farkında olan ve bunların sürdürülebilirliğini sağlayabilen, fikirlerini kamuya açık olarak paylaşabilen ve yeni politika önerebilmeleri için neler yapılması gerektiğini bilen bireylerin yetişmesine yardımcı olacaktır (Saavedra, 2012). Bu doğrultuda, bireylerin temel yurttaşlık bilgisini kazanmalarının yanında, eleştirel düşünebilen yurttaşlar olarak yetişmeleri, sosyal sorunlara çözüm üretebilmelerine, haber öğelerini analiz edebilmelerine, önyargılarından kurtularak değerlendirmeler yapabilmelerine ve seçimlerini daha etkili bir biçimde gerçekleştirebilmelerine olanak sağlayacaktır (Savedra ve Opfer, 2012b). Son olarak, küresel göçler, uluslararası savaşlar, iklim değişiklikleri, uluslararası pazarlar ve teknolojik ilerlemeler gibi faktörler ülkelerin, devletlerin ve bireylerin küresel olarak birbirine bağlı bir ekonominin, ekosistemin ve siyasi bir ağın parçası olduğunu göstermektedir (Savedra ve Opfer, 2012b). Bu küreselleşme, dünyanın dört bir yanındaki bireylerin ulusal sınırların ötesindeki insanlarla nasıl iletişim kuracaklarını, iş birliği yapacaklarını ve sorunları nasıl çözeceklerini öğrenmelerinde 21. yüzyıl becerilerinin gerekliliğini ve önemini bir kez daha ortaya çıkarmaktadır (Osler ve Vincent, 2002). Nitekim yaratıcılık, azim ve problem çözmeyle bütünleşmiş iş birliği becerileri giderek daha gerekli hale gelmektedir (Jacobson-Lundeberg, 2016; Larson ve Miller, 2011).

$\mathrm{Bu}$ nedenler doğrultusunda, 21. yüzyıl becerilerine yönelik anlayışın güçlendirilmesi amacıyla, uluslararası örgütler, kurum ve kuruluşlar; devletler ve danışmanlık şirketlerinin desteğiyle birçok çerçeve (örneğin, ATC21S, P21-21. Yüzyıl Becerileri Ortaklığı vb.) hazırlamıştır (Voogt ve Roblin, 2010). Benzer şekilde, son yıllarda, dünya çapındaki eğitim sistemleri de (örneğin, Çin, Hong Kong, Japonya, Singapur, Birleşik Devletler ve Finlandiya) 21. yüzyılda başarı için gerekli olan becerileri, bilgileri ve tutumları geliştirmeye dair reform çalışmaları yapmaya başlamıştır (Saavedra ve Opfer, 2012b; Sylva, Sammons, Melhuish, Siraj ve Taggart, 2020). Özellikle eğitim sisteminin temeli olarak kabul edilen erken çocukluk eğitimi döneminden başlayarak okulların eğitim programlarında, bu becerilerin kazandırılmasına yönelik amaçların, öğretme, öğrenme ve değerlendirme yaklaşımlarının nasıl yer alacağının belirlenmesine yönelik girişimler hız kazanmıştır (Care, Kim, Vista ve Anderson, 2018; Huber ve Bates, 2016; Ramey, 2016). Bu durum, 21. yüzyıl bağlamında önemli olduğu düşünülen becerilerin tanımlanmasına; genelde eğitim sistemlerine dahil edilmesine ve özelde ise, bu becerilerin gelişimini desteklemek için eğitim programlarında değişiklikler yapılmasına yönelik yoğun bir ilginin bulunduğuna işaret etmektedir.

\section{Erken Çocukluk Eğitimi Bağlamında 21. Yüzyıl Becerileri}

Öğrencileri, 21. yüzyılda başarılı bir işe, vatandaşlığa ve yaşama hazırlamak oldukça karmaşık bir süreçtir. Özellikle, öğrencilere dersler ve ders kitapları aracılığıyla bilgi aktarımının yapıldığı günün şartlarına uymayan bir eğitim sisteminin, dünyanın büyük bir kısmında zorunlu temel eğitim döneminde baskın biçimde benimsenmeye devam edilmesi, öğrencilerin 21. yüzyıl becerilerini kazanamamalarının temel nedeni olarak gösterilebilir (Organization for Economic Cooperation and Development [OECD], 2009). Bu durum, mevcut eğitim sistemlerinde öğrencilerin bilgiyi öğrenme fırsatlarına sahip olmasına ancak bilgiyi yeni bağlamlara uygulama, bilgiyi kullanarak karmaşık yollarla iletişim kurma, sorunları çözme veya yaratıcıllı̆ı geliştirme konularında genellikle deneyim kazanamamalarına yol açmaktadır. Dolayısıyla, bilgi aktarımı 
yaklaşımı, 21. yüzyıl becerilerinin öğretilmesinde etkili bir yol olmamaktadır. Bu temel nedene ek olarak, öğrencilere 21. yüzyıl becerilerinin açıkça öğretilmemesi, onların bu becerileri geliştirmelerinin önündeki ikinci engel olarak ortaya çıkmaktadır. Diğer bir ifadeyle, bu beceriler tipik olarak ayrı dersler bağlamında (örneğin, düşünme gibi) öğretilmemektedir. Dolayısıyla, tartışma ve yapılandırılmış sınıf söyleşileri gibi aktif öğrenme stratejilerini kullanan öğretmenlerin bile 21. yüzyıl becerilerini genellikle açıkça vurgulamadığı görülmektedir (OECD, 2009; Schleicher, 2012). Son olarak, 21. yüzyıl becerilerinin geleneksel ölçmedeğerlendirme yöntemleriyle değerlendirilmesinin zorluğu, hesap verebilirliğin ve belgelendirmeyle sonuçlanan sınavların baskın olduğu eğitim sistemlerinde, öğretmenlerin bu becerilerin öğretimine sınıf öncelikleri arasında yer vermemesine neden olmaktadır (Saavedra ve Opfer, 2012b). Bu nedenler bağlamında, mevcut eğitim programlarında öğrencilerin neden 21. yüzyıl becerilerini kazanamadıkları anlaşılır bir görünüm elde etmektedir.

Oysaki erken çocukluk eğitiminin doğası gereği, 21. yüzyıl becerilerinin kazanılmasını güçleştiren bu engellerden daha az etkileneceği veya bazılarından hiç etkilenmeyeceği üç gerekçeden ötürü ileri sürülebilir. Birincisi, çocukların gelecekteki eğitim yaşamlarının temelini oluşturan erken çocukluk eğitiminde, çocuklara bilgi aktarımından ziyade, etkinlikler ve projelerle deneyim kazandırma amaçlanmaktadır. Nitekim çocuklar etkinlikler ve projeler aracılığıyla eleştirel düşünme, yaratıcılık, araştırma, bilgiye ulaşma ve yeni bilgi üretme, iş birliği içinde çalışma becerilerini deneyimleyebilecekleri fırsatlar yakalayabilmektedirler (Helm ve Katz, 2001). İkincisi, erken çocukluk eğitimi, 21. yüzyıl becerilerinin doğrudan ele alınabileceği etkinliklerin planlanması açısından sağlam bir zemin hazırlamaktadır. Nitekim erken çocukluk eğitiminde yapılan eğitsel etkinliklerle çocukların belirli becerileri edinmeleri hedeflenebilir. Etkinlikler, bir konu ya da tema çerçevesinde şekillendirilebilmektedir. Ancak, konu ya da tema, çocukların o etkinlik çerçevesinde kazanması planlanan becerileri sunmada bir araç olarak kullanılmalıdır (Helm ve Katz, 2001; Kostelnik, Soderman, Whiren ve Rupiper, 2019; MEB, 2013a). Örneğin, Ata-Aktürk, Demircan, Şenyurt ve Çetin'in (2017) Fen, Teknoloji, Mühendislik ve Matematik (STEM) eğitimi açısından Milli Eğitim Bakanlığı (MEB) okul öncesi eğitim programını inceledikleri çalışmalarında, mevcut okul öncesi eğitim programının, çocukların birçok 21. yüzyıl becerisini (örneğin, yaratıcılık, problem çözme, eleştirel düşünme) kazanabilecekleri gerçek yaşam problemleri için oldukça uygun ve etkili bir kaynak olduğunu ifade etmektedir. Üçüncüsü, erken çocukluk eğitiminde başvurulan ölçme-değerlendirme yöntemleri, 21. yüzyıl becerilerinin değerlendirilmesi için uygun yöntemler olarak kabul edilebilir. Erken çocukluk eğitiminde eğitimin çıktılarını değerlendirmek için geleneksel ölçme-değerlendirme yöntemleri uygulanmamaktadır. Bunların yerine, gözlem, gelişim raporları, portfolyolar gibi alternatif ölçme-değerlendirme yöntemleri kullanılmaktadır (Gullo, 2005; Wortham ve Hardin, 2016). Sonuçtan çok süreç odaklı bir yaklaşımın benimsendiği bu tür ölçme-değerlendirme yöntemlerinde, öğrencilerden bilgileri hatırlaması değil, etkin olarak katıldıkları ve kendileri tarafından yapılandırılan deneyimleri, öğrenmeleri ve gelişimleri değerlendirmeleri beklenmektedir (Wiggins, 1998; Windschitl, 2002). Bu nedenle, söz konusu yöntemler, eleştirel, yaratıcı ve yansıtıcı düşünme ve iş birliği, iletişim gibi pek çok 21. yüzyıl becerisinin değerlendirmesini mümkün kılmaktadır. Dolayısıyla, 21. yüzyıl becerilerinin erken yaşlarda kazandırılmasında erken çocukluk eğitiminin uygun bir ortam sağlayabileceği söylenebilir.

Ayrıca, geleceğin öğrencilerinin 21. yüzyılda karşılaşacakları zorlukların üstesinden gelmek için okul öncesi dönemde çok iyi bir başlangıç yapmaları gerekmektedir. Çocukların gelecekte akıl yürütme, yaratıcı düşünme, verileri analiz etme ve iş birliği içinde çalışmalarına yardımcı olacak 21. yüzyıl becerilerinin öğretimine erken yaşlarda, özellikle okul öncesi dönemde başlanmalıdır. Nitekim sinirbilimciler, eğitimciler ve erken çocukluk gelişimi uzmanları, erken deneyimlerin beynin gelişimi ve öğrenme üzerinde büyük bir etkisi olduğu konusunda hemfikirdir. Beyin, çok çeşitli deneyimlere, etkileşimlere ve sosyal çevrelere uyum sağlamak için bebeklik döneminden beş yaşına kadar en büyük esnekliğe sahiptir. Bu nedenle, erken yaşlarda sosyal, duygusal, bilişsel ve dil becerileri gibi 21. yüzyıl becerilerini de geliştirmek kritik derecede önemlidir (P21-A Network of Battelle for Kids, 2019b). Nitekim son on yılda, erken çocukluk eğitiminde çocukların sosyal ve akademik yeterlilikleri arasında daha dengeli bir yaklaşımın benimsenmesinin yanı sıra öz düzenleme, problem çözme, yaratıcılık ve iş birliği gibi 21. yüzyıl becerilerin gelişiminin vurgulandığı görülmektedir (Sylva, Pastori, Lerkkanen, Ereky-Stevens ve Slot, 2016). Gerçekten de tarihsel süreç içerisinde, 
birçok felsefi akım ve yaklaşım doğrultusunda sürekli olarak kendini yenileyen bir yapıda olan erken çocukluk eğitimi (Hinitz, 2013; Lascarides ve Hinitz, 2000), 21. yüzyılda da bilgi çağının gerekliklerine ayak uydurma çabası içerisindedir. Benzer bir biçimde, Türkiye' de uygulanan ve 2013 yılında en güncel halini alan okul öncesi eğitim programında, açık olarak 21. yüzyıl becerilerine vurgu yapılmaktadır. Programın genel yapısının tanıtıldığı bölümde yer alan “... Bu programda 21. yüzyılın gereksinim duyduğu bireyi yetiştirmek, ulusal özellik ve gereksinimleri karşılamak amacıyla farklı öğrenme kuram ve modellerindeki çocuk merkezli uygulamalardan yararlanılarak bir senteze ulaşılmıştır." ifadesi, programın 21. yüzyıl becerileri gözetilerek hazırlandığını belirtmektedir (MEB, 2013a, s. 15).

Bu bağlamda, mevcut araştırma MEB 2013 okul öncesi eğitim programının sistematik ve açık bir biçimde 21. yüzyıl becerilerini ne oranda ve nasıl içerdiği sorusuna yanıt arama ihtiyacından ortaya çıkmıştır. Nitekim sürdürülebilir program geliştirme açısından, mevcut programların eleştirel bir bakış açısıyla analiz edilmesi, 21. yüzyıl becerilerinin eğitim programlarıyla bütünleştirilmesi için öğretmen, program ve eğitim sistemi açısından neler gerektiğinin daha iyi anlaşılmasında oldukça önemlidir.

\section{Araştırmanın Amacı, Soruları ve Önemi}

Bu araştırma, MEB 2013 okul öncesi eğitim programı ve etkinlik kitabının 21. yüzyıl becerileri açısından sistematik olarak incelenmesini amaçlamaktadır. Bu doğrultuda, araştırmada şu sorulara yanıt aranmaktadır:

1. 21. yüzyıl becerileri, MEB 2013 okul öncesi eğitim programının genelinde nasıl yer almaktadır?

2. 21. yüzyıl becerileri, MEB 2013 okul öncesi eğitim programının kazanım ve göstergelerinde nasıl yer almaktadır?

3. 21. yüzyıl becerileri, etkinlik kitabında nasıl yer almaktadır?

Alanyazın incelendiğinde, genellikle Sosyal Bilgiler ve Türkçe dersleri öğretim programlarının 21. yüzyıl becerileri bağlamında incelendiği görülmektedir (Bal, 2018; Belet-Boyacı ve Güner-Özer, 2019; Kaymakc1, 2009; Otuz, Görkaş-Kayabaşı ve Ekici, 2018). Okul öncesi eğitim programının ise, yalnızca kazanımları ve göstergelerinin 21. yüzyıl becerileri açısından incelendiği anlaşılmaktadır (Koçin ve Tuğluk, 2020; Tuğluk ve Özkan, 2019). Bu bağlamda, mevcut araştırma, okul öncesi eğitim programındaki bütün tanıtıcı bölümler, gelişim özellikleri, beş gelişim alanına yönelik kazanım ve göstergeler, okul öncesi eğitimin planlanması ve uygulanmasına yönelik bilgiler (öğrenme merkezleri ve etkinlik türleri) ve eğitimin değerlendirilmesi (çocukların değerlendirilmesi, programın değerlendirilmesi ve öğretmenin kendini değerlendirmesi) bölümleri ile etkinlik kitabındaki örnek etkinlikler 21. yüzyıl becerileri açısından incelemektedir. Bu yönüyle mevcut araştırma, çocukların 21. yüzyıl becerilerini etkili bir biçimde kazanabilmeleri için bu becerilerin açık bir biçimde ve doğrudan okul öncesi eğitim programında nasıl deneyimleyebileceklerinin; diğer bir ifadeyle, 21. yüzyıl becerilerinin okul öncesi eğitim programıyla bütünleştirilmesi için neler gerektiğinin daha iyi anlaşılmasına katkıda sağlayabilir.

\section{Yöntem}

$\mathrm{Bu}$ araştırmada, yazılı belgelerin veri kaynağı olarak titizlikle ve sistematik olarak incelenmesinde kullanılan nitel araştırma yöntemlerinden doküman analizi benimsenmiştir. Doküman analizi, basılı ve elektronik materyaller olmak üzere tüm belgeleri incelemek ve değerlendirmek için kullanılan sistemli bir yöntemdir (Bowen, 2009). Bu kapsamda, MEB 2013 okul öncesi eğitimi programı ile programın uygulanmasına rehberlik eden etkinlik kitabı, 21. yüzyıl becerileri bağlamında incelenmiştir. 21. yüzyıl becerileri, 21. Yüzyıl Becerileri Erken Öğrenme Çerçevesi (21st Century Skills Early Learning Framework-P21 ELF) temel alınarak incelenmiştir.

\section{Verilerin Toplanması}

Araştırmada, MEB 2013 okul öncesi eğitimi programı ve etkinlik kitabının incelenmesinde veri toplama aracı olarak, 21. Yüzyıl Becerileri Erken Öğrenme Çerçevesi (P21-EÖÇ) kullanılmıştır. P21 EÖÇ, erken çocukluk dönemindeki öğrenciler için 21. yüzyıl becerilerinin açıklamalarını ve öğrenme çıktıları ile öğrenme 
ortamlarına ilişkin ayrıntılı örnekler içermektedir (P21-A Network of Battelle for Kids, 2019c). Ayrıca, diğer birçok çerçevede (örneğin, $A B, O E C D$, EnGauge) yer alan 21. yüzyıl beceri setlerini ayrıntılı bir biçimde kapsamaktadır (Voogt ve Roblin, 2012). Bu özellikleriyle, P21 EÖÇ, konuyla ilgili literatürde birçok araştırmada sıklıkla tercih edilen bir çerçevedir (Chu ve diğerleri, 2017; Dede, 2010; Voogt ve Roblin, 2012). Bu nedenle, mevcut araştırmada, MEB 2013 okul öncesi eğitimi programı ve etkinlik kitabında yer alan 21. yüzyıl becerileri, P21 EÖÇ kapsamındaki öğrenme ve yenilik becerileri, yaşam ve kariyer becerileri ile bilgi, medya ve teknoloji becerileri temel alınarak incelenmiştir.

P21- 21. Yüzyıl Becerileri Erken Öğrenme Çerçevesi. 21. yüzyıl becerileri, çeşitli kurum (örneğin, Avrupa Birliği, OECD, UNESCO) ve kuruluşlar (örneğin, EnGauge, ATC21S, P21-21. Yüzyıl Becerileri Ortaklığı) tarafından farklı çerçeveler bağlamında tanımlanmış ve sınıflandırılmıştır (Dede, 2010; Voogt ve Roblin, 2010). Bu çerçeveler arasında yer alan P21- 21. Yüzyıl Becerileri Erken Öğrenme Çerçevesi (P21-EÖÇ), 21. yüzyıl becerilerinin program politikalarına ve eğitsel uygulamalarına yön vermesinde diğer çerçeveler gibi oldukça önemlidir (Binkley ve diğerleri, 2012). P21-EÖÇ, 2002 y1lında Amerika Birleşik Devletleri (ABD)'nde, iş dünyası, eğitim liderleri ve politika yapıcıların iş birliğiyle kurulan ve ABD Hükümeti ile bazı özel kuruluşların (ör. Microsoft Corporation, Cisco Systems, Apple Computer, Dell Computer Corporation vb.) da güçlü bir biçimde desteklediği P21-21. Yüzyıl Becerileri Ortaklığı tarafından hazırlanan bir çerçevedir. Bu çerçeve, 21. yüzyılda iş ve günlük yaşamın zorluklarıyla başa çıkabilmeleri için bireylere okul öncesi dönemden başlayarak kazandırılması gereken bilgi ve becerileri, hem de bu bilgi ve becerilerin desteklenmesinde kullanılabilecek sistemleri kapsamlı bir biçimde sunmaktadır (Voogt ve Roblin, 2010).

P21 EÖÇ, özel olarak okul öncesi dönem için hazırlanmış olup hem resmi (örneğin, gündüz bakım evleri ve anaokulları) hem de resmi olmayan ortamlarda (örneğin, kamplar, müzeler ve evler) kullanılmak üzere tasarlanmıştır (P21-A Network of Battelle for Kids, 2019c). Çerçeve, eğitimcileri, yöneticileri, okul öncesi dönem çocukları için hizmet sağlayanları ve politika yapıcıları 21. yüzyıl becerilerini okul öncesi eğitim uygulamalarıyla bütünleştirmeleri için teşvik etmek amacıyla hazırlanmıştır (Dede, 2010). P21 EÖÇ, 21. yüzyılda öğrencilerin ihtiyaç duyduğu beceriler ve öğrenmesi gereken yararlı konular ile bu becerilerin desteklenmesinde kullanılabilecek sistemleri göstermektedir (Şekil 1).

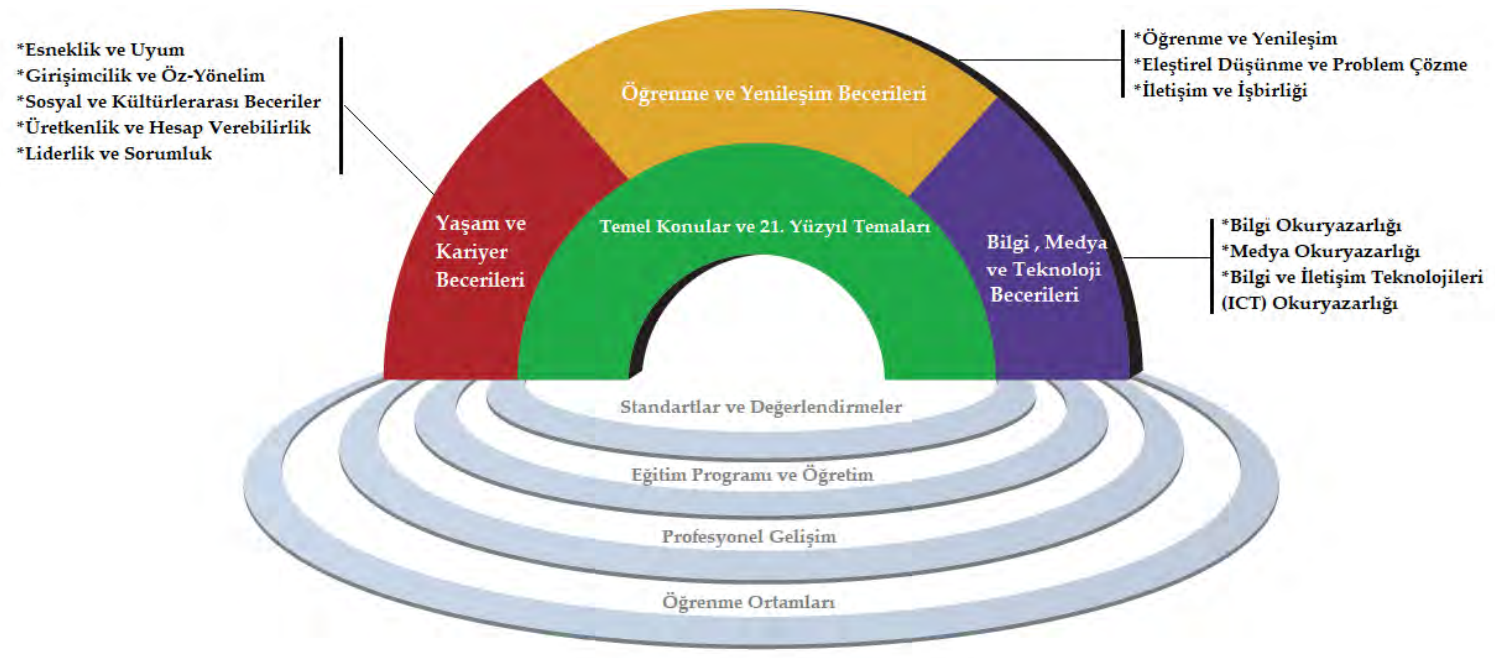

Şekil 1. P21- 21. Yüzyıl Becerileri Erken Öğrenme Çerçevesi

Detaylı olarak, P21 EÖÇ, iki ana bölümden oluşmaktadır. Bunlar, 21. yüzyıl öğrenme çıktıları ve 21. yüzyıl destek sistemleridir. Öğrenme çıtıları; öğrencilerin iş ve günlük yaşamda başarılı olmak için kazanmaları gereken konu ve becerilerle ilgili dört temel unsuru içermektedir (P21-A Network of Battelle for Kids, 2019c). $\mathrm{Bu}$ unsurlar, temel konular ve 21. yüzyıl temaları, öğrenme ve yenilik becerileri, yaşam ve kariyer becerileri ile bilgi, medya ve teknoloji becerileridir.

Temel konular İngilizce, okuma veya dil sanatları, dünya dilleri, sanat, matematik, ekonomi, bilim, coğrafya, tarih ve devlet yönetimi ve vatandaşlı̆̆ içermektedir. Bu temel konulara ek olarak, küresel 
farkındalık, finans, ekonomi, işletme ve girişimcilik okuryazarlığı, yurttaşlık okuryazarlığı, sağlık okuryazarlığı, çevre okuryazarlığı gibi 21. yüzyılın disiplinler arası temalar, temel konulara dönüştürülerek ele alınabilir.

P21 EÖÇ kapsamında yer alan 21. yüzyıl öğrenme çıtıları; öğrenme ve yenilik becerileri, yaşam ve kariyer becerileri ile bilgi, medya ve teknoloji becerilerini de kapsamaktadır.

- Öğrenme ve yenilik (inovasyon) becerileri; gittikçe karmaşıklaşan yaşam ve çalışma ortamlarına hazırlanan bireyler için gerekli yaratıcılık ve yenilik, eleştirel düşünme ve problem çözme ile iletişim ve iş birliğiyle ilişkili becerileri içermektedir:

- Yaratıcılık ve yenilik becerileri, düşüncelerini ve duygularını yaratıcı biçimde (örneğin, resim, yazı, çizim, heykel, drama, dans, hareket ve bilimsel keşif) ifade edebilme, çeşitli fikir üretme tekniklerini (örneğin, beyin fırtınası) kullanabilme, yeni ve değerli fikirler üretebilme, çalışmalarında özgünlük ve yaratıcılık gösterebilme becerilerdir.

- Eleştirel düşünme ve problem çözme becerileri, karşılaşılan farklı türlerdeki alışılmadık problemlere hem geleneksel hem de yaratıcı çözümler sunabilme, duruma uygun olarak çeşitli akıl yürütme yöntemlerini (tümevarım, tümdengelim vb.) kullanabilme, farklı bakış açılarını netleştirmeye ve daha etkili çözümler üretmeye yönelik sorular sorabilme becerileridir.

- İletişim becerileri, çeşitli biçim ve bağlamlarda sözlü, yazılı ve sözsüz iletişim becerilerini kullanarak düşünce ve fikirleri etkili bir şekilde ifade edebilme, iletişimi çeşitli amaçlar için kullanabilme (örneğin, bilgilendirmek, talimat vermek, motive etmek ve ikna etmek) ve karşıdan gelen bilgi, değer, tutum ve niyetleri çözümlemek için etkili dinleme becerileridir.

- İşbirliği becerileri, farklı gruplarda/takımlarda etkili bir şekilde çalışabilme ve takım çalışmalarında ortak sorumluluk üstlenebilme becerileridir.

- Yaşam ve kariyer becerileri; küresel rekabetin var olduğu bilgi çağında başarılı olabilmek için bireylerin ihtiyaç duyduğu esneklik ve uyum, girişimcilik ve öz-yönetim, üretkenlik ve hesap verebilirlik, liderlik ve sorumluluk becerileri ile sosyal ve kültürlerarası becerileri kapsamaktadır.

- Esneklik ve uyum becerileri, çeşitli rollere, mesleki sorumluluklara, programlara ve bağlamlara uyum sağlayabilme, karmaşık ve önceliklerin değiştiği ortamlarda etkin olarak çalışabilme, aksiliklerle, övgülerle ve eleştirilerle olumlu bir şekilde başa çıkabilme becerileridir.

- Girişimcilik ve öz-yönetim becerileri, bir çocuğun doğal merakı ve etrafındaki dünyayı daha iyi anlama arzusuyla ilgilidir. Hedefler belirleyebilme ve bu hedeflere ulaşmak için stratejiler geliştirebilme, zamanı etkili bir biçimde kullanabilme, başkalarının gözetimi olmaksızın görevleri tanımlayabilme, öncelik sırasına koyabilme ve tamamlayabilme gibi becerileri içerir.

- Sosyal ve kültürlerarası beceriler, başkalarının duygularını ve düşüncelerini anlayabilme, empati kurabilme, kültürel farklılıklara saygı duyabilme ve çeşitli sosyal ve kültürel geçmişlere sahip insanlarla etkili bir şekilde çalışabilme, farklı fikir ve değerlere karşı açık fikirli olabilme, yeni fikirler yaratmada sosyal ve kültürel farklılıklardan yararlanabilme becerileridir.

- Üretkenlik ve hesap verebilirlik becerileri, engeller ve baskılar karşısında bile hedef belirleyebilme ve bu hedeflere ulaşabilme, amaçlanan sonuca ulaşmak için bir işi planlayabilme ve yönetebilme ile yüksek kaliteli ürünler üretebilme becerileridir.

- Liderlik ve sorumluluk becerileri, kişilerarası sosyal ve problem çözme becerilerini kullanarak başkalarını etkilemek ve bir hedefe yöneltmek, ortak bir hedefe ulaşmak için başkalarının güçlü yönlerinden yararlanmak, örnek ve özverili davranarak başkalarına en iyiye ulaşmaları için ilham vermek, etki ve gücü kullanırken dürüstlük ve etik davranışlar sergilemek ve içinde bulunduğu topluluğun çıkarları doğrultusunda sorumluluk sahibi olarak davranmak gibi becerileri içerir.

- Bilgi, medya ve teknoloji becerileri; bilgi çağı olarak adlandırılan teknolojinin ve medyanın etkisinin yoğun bir biçimde hissedildiği 21. yüzyılda başarılı vatandaşlar ve çalışanlar olabilmek için gerekli olan bilgi okuryazarlığı, medya okuryazarlığı ile bilgi ve iletişim teknolojileri okuryazarlığı becerilerinde oluşmaktadır.

- Bilgi okuryazarlığı, bilgiye ulaşabilme, bilgiyi eleştirel bir biçimde değerlendirebilme, bilgiyi mevcut sorunlara yaratıcı çözümler bulmada kullanabilme, çeşitli kaynaklardan bilgi akışını 
yönetebilme ile bilginin erişimine ve kullanımına ilişkin etik ve yasal konularda temel bir anlayışa sahip olabilme becerileridir.

- Medya okuryazarlığı, medya iletilerinin nasıl, neden ve hangi amaçlarla oluşturulduğunu anlayabilme, bireylerin iletileri nasıl farklı yorumladığını, farklı değer yargılarının ve bakış açılarının nasıl ele alındığını ve medyanın inanç ve davranışları nasıl etkilediğini anlayabilme ile medyanın erişimine ve kullanımına ilişkin etik ve yasal konularda temel bir anlayışa sahip olabilme becerileridir.

- Bilgi ve iletişim teknolojileri okuryazarlığı, bilgiyi araştırmak, düzenlemek, değerlendirmek ve iletmek için teknolojiyi bir araç olarak kullanabilme ile bilgi teknolojilerinin erişimine ve kullanımına ilişkin etik ve yasal konularda temel bir anlayışa sahip olabilme becerileridir.

P21, tüm öğrencilerin 21. yüzyıl becerilerinin gelişimine katk1 sağlayacak öğrenme deneyimlerinin oluşturulması için beş destek sistemi belirlemiştir. Bunlar; 21. yüzyıl standartları, 21. yüzyıl becerilerinin değerlendirilmesi, 21. yüzyıl eğitim programı ve öğretim, 21. yüzyıl mesleki gelişim ve 21. yüzyıl öğrenme ortamlarıdır.

MEB 2013 Okul Öncesi Eğitimi Programı ve Etkinlik Kitabı. MEB 2013 okul öncesi eğitim programı, okul öncesi eğitim kurumlarına devam eden çocukların zengin öğrenme deneyimleri aracılığıyla motor, sosyal ve duygusal, dil ve bilişsel gelişim gelişimlerini bütüncül olarak desteklemeyi, öz bakım becerilerini kazanmalarını ve ilkokula hazır olmalarını sağlamayı hedeflemektedir. MEB 2013 okul öncesi eğitim programı ve etkinlik kitabının temel özelliklerine Tablo 1'de yer verilmiştir (MEB 2013a, b; Yazar, 2017).

Tablo 1. MEB 2013 Okul Öncesi Eğitim Programı ve Etkinlik Kitabının Temel Özellikleri

\begin{tabular}{|c|c|c|}
\hline & Temel Özellikler & Açıklamalar \\
\hline \multirow[t]{13}{*}{ Program } & Tanıtıcı Bölümler & $\begin{array}{l}\text { Programın ilk bölümünde, Türk Milli Eğitiminin temel amaçları, okul öncesi } \\
\text { eğitiminin amaçları ve temel ilkeleri, okul öncesi döneminin önemi, okul öncesi } \\
\text { eğitimi programının tanıtımına ilişkin açıklamalar bulunur. }\end{array}$ \\
\hline & $\begin{array}{l}\text { Gelişimsel Özellikler, } \\
\text { Kazanımlar ve Göstergeler }\end{array}$ & $\begin{array}{l}\text { Program; motor, sosyal ve duygusal, dil ve bilişsel gelişimleri desteklemeyi } \\
\text { amaçlar. Her bir gelişim alanı için, çocuklar tarafından ulaşılması gereken } \\
\text { kazanımlar ve bu kazanımların gözlemlenebilir formu olan göstergeler bulunur. }\end{array}$ \\
\hline & Okul Öncesi Eğitimin & Öğrenme merkezleri, günlük eğitim akışında yer alan etkinliklerde ele alınan \\
\hline & $\begin{array}{l}\text { Ortamı ve Öğrenme } \\
\text { Merkezleri }\end{array}$ & $\begin{array}{l}\text { kazanım ve göstergeler doğrultusunda seçilmiş farklı materyalleri barındıran, } \\
\text { birbirinden çeşitli malzemelerle ayrılmış olan oyun alanlarıdır. Okul öncesi } \\
\text { eğitimi kurumlarında bulunması önerilen merkezler; blok, kitap, müzik, sanat, } \\
\text { fen ve dramatik oyun merkezleridir. }\end{array}$ \\
\hline & Etkinlikler & $\begin{array}{l}\text { Etkinlik çeşitleri; Türkçe, sanat, drama, müzik, hareket, oyun, fen, matematik, } \\
\text { okuma yazmaya hazırlık ve alan gezileri şeklindedir. Öğretmen veya çocuklar } \\
\text { tarafından yapılandırılmış/ yarı yapılandırılmış/yapılandırılmamış etkinlikler } \\
\text { sınıf içinde yapılabileceği gibi açı havada da yapılabilir. Etkinlikler bireysel, } \\
\text { küçük grup veya büyük grup şeklinde planlanıp uygulanabilir. }\end{array}$ \\
\hline & Aylık Eğitim Planı & $\begin{array}{l}\text { Aylık plan, bir öğretmenin çalıştığı çocuk grubunun gelişimini desteklemek için } \\
\text { etkinlik oluşturmak üzere dikkate alacağı kazanım ve göstergeleri, kavramları, } \\
\text { alan gezilerini, özel gün ve haftalar ile aile katılımı ve değerlendirme süreçlerini } \\
\text { içeren bir çalışma planıdır. }\end{array}$ \\
\hline & Günlük Eğitim Akışı & $\begin{array}{l}\text { Günlük eğitim akışı, öğretmenin o gün yapacağı çalışmalara düzenli bir şekilde } \\
\text { yer verdiği çerçeve bir plandır. Güne başlama zamanı, oyun zamanı, etkinlik } \\
\text { zamanı ve günü değerlendirme zamanı ile beslenme ve dinlenme zamanı gibi } \\
\text { rutin etkinlikleri içerir. }\end{array}$ \\
\hline & Çocukların & Gelişim gözlem formları ve gelişim raporları, çocuğun gelişimini izlenme \\
\hline & Değerlendirilmesi & $\begin{array}{l}\text { sürecinde kullanılabilir. Ayrıca, her çocuk için oluşturulan gelişim dosyalarında } \\
\text { çocukların yaptığı bütün çalışmalar, ailelerden gelen mektup gibi belgeler ve } \\
\text { çocukların gelişim gözlem formları ile gelişim raporları biriktirilebilir. }\end{array}$ \\
\hline & Programın & Programın değerlendirilmesi, öğretmenlerin hazırladıkları ve uyguladıkları aylık \\
\hline & Değerlendirilmesi & $\begin{array}{l}\text { plan ve etkinliklerin bütün boyutlarının ele alınmasıyla gerçekleşir. Günlük } \\
\text { eğitim sürecinin ve etkinliklerin değerlendirilmesi, etkinlik ile ilgili konuşmalar, } \\
\text { çalışma kăğıtları, sunumlar, hafıza kartları, çizimler, sergiler, posterler ve } \\
\text { fotoğraflar ile yapılabilir. }\end{array}$ \\
\hline & Öğretmenin & Öğretmenlerin kendilerini değerlendirmeleri, güdülenmelerini, yaratıcılıklarının \\
\hline & Değerlendirilmesi & artmasını, eksikliklerini görerek kendilerini güçlendirebilmelerini sağlar. \\
\hline
\end{tabular}




\begin{tabular}{|c|c|c|}
\hline & Ekler & $\begin{array}{l}\text { Programın ekler bölümünde, gelişim gözlem formu, gelişim raporu, aylık eğitim } \\
\text { planı formatı, etkinlik planı formatı, kavramlara aylık eğitim planlarında yer } \\
\text { verme durumu çizelgesi, kazanım ve göstergelere aylık eğitim planlarında yer } \\
\text { verme durumu çizelgesi, belirli gün ve haftalar listesi, yarım günlük eğitim akışı } \\
\text { formatı, tam günlük eğitim akışı formatı, örnek yarım günlük eğitim akışı ile özel } \\
\text { gereksinimli çocukları desteklemede dikkat edilmesi gereken noktalar yer alır. }\end{array}$ \\
\hline $\begin{array}{l}\text { Etkinlik } \\
\text { Kitabı }\end{array}$ & $\begin{array}{l}48-72 \text { aylık çocuklar için } 40 \\
\text { aktivite }\end{array}$ & $\begin{array}{l}\text { 36-48, } 48-60 \text { ve } 60-72 \text { aylık çocuklar için program kitabında yer alan bazı kazanım } \\
\text { ve göstergeler ile kavramlar ele alınarak öğretmenlere örnek olması amacıyla } \\
\text { hazırlanmış etkinlikler bulunur. Her bir etkinlikte, kazanımlar ve göstergeleri, } \\
\text { materyaller, sözcükler, kavramlar, öğrenme süreci, değerlendirme, aile katılımı ve } \\
\text { özel gereksinimli çocuklar için uyarlama bölümleri yer alır. }\end{array}$ \\
\hline
\end{tabular}

\section{Veri Analiz Süreci}

Araştırma sorularının yanıtlanması amacıyla elde edilen verilerin incelenmesinde betimsel analiz kullanılmıştır. Betimsel analiz, önceden belirlenmiş bir çerçeveye bağlı olarak nitel verilerin işlenmesi, bulguların tanımlanması ve tanımlanan bulguların yorumlanması adımlarını içeren nitel bir veri analiz yaklaşımıdır (Yıldırım ve Şimşek, 2013). Bu yaklaşımda, gözlem, görüşme veya dokümanların incelenmesi yoluyla elde edilen yazılı biçimdeki veriler, çalışmanın güvenirliğini artırmak, yanlılığı azaltmak, çalışmada tema/kategoriler arası karşılaştırma yapmak ve küçük ölçekli bir çalışmanın daha sonra geniş bir örneklemle tekrarlanabilirliğini artırmak amaçlarıyla basit yüzde hesapları ve frekans yardımıyla sayısallaştırılabilir (Yıldırım ve Şimşek, 2013). Araştırma kapsamında, MEB 2013 okul öncesi eğitimi programı ve etkinlik kitabından elde edilen veriler, betimsel analiz yoluyla dört aşamada incelenmiştir (Yıldırım ve Şimşek, 2013).

İlk aşamada, P21 EÖÇ kapsamındaki öğrenme ve yenilik becerileri, yaşam ve kariyer becerileri ile bilgi, medya ve teknoloji becerileri temalar olarak belirlenmiştir. İkinci aşamada, tematik çerçeveye göre, MEB 2013 okul öncesi eğitimi programı ve etkinlik kitabı sistematik olarak incelenmiştir. Eğitim programındaki bütün tanıtıcı bölümler, gelişim özellikleri, beş gelişim alanına yönelik kazanım ve göstergeler, okul öncesi eğitimin planlanması ve uygulanmasına yönelik bilgiler (öğrenme merkezleri ve etkinlik türleri) ve eğitimin değerlendirilmesi (çocukların değerlendirilmesi, programın değerlendirilmesi ve öğretmenin kendini değerlendirmesi) bölümleri ile etkinlik kitabındaki örnek etkinlikler betimsel analizin analiz birimlerini oluşturmuştur. Söz konusu birimlerde, 21. yüzyıl becerileriyle ilişkili olabilecek ifadeler belirlenmiş ve tematik çerçeveye göre sınıflandırılmıştır. Üçüncü aşamada, temalar altında sınıflandırılan 21. yüzyıl becerilerinin, her bir araştırma sorusunun yanıtına karşılık gelecek şekilde frekansları ve bu frekanslara bağlı olarak yüzde oranları hesaplanmıştır. Tüm hesaplamalar, bilgisayar ortamında ve SPSS 20 programı kullanılarak gerçekleştirilmiştir. Ayrıca, sonuçta elde edilen sayısal bulgular, tablolar yardımıyla sunulmuş ve doğrudan alıntılarla desteklenmiştir. Dördüncü aşamada ise, tablolaştırılan bulguların açılanması, ilişkilendirilmesi ve anlamlandırılması yapılmıştır.

Betimsel analiz sürecinde ilk olarak, araştırmacılar MEB 2013 okul öncesi eğitimi programını ve etkinlik kitabını birbirlerinden bağımsız olarak analiz etmiştir. Daha sonra, araştırmacıların analizleri karşılaştırılarak örtüşen ve örtüşmeyen verilerin sayısı tespit edilmiştir. [Güvenirlik = örtüşenlerin sayısı / (örtüşenler + örtüşmeyenler sayıs1) x 100] formülü (Miles ve Huberman, 2002) kullanılarak hesaplanan güvenirlik katsayısı .92 bulunmuştur. Miles ve Huberman'a (2002) göre, bu formül ile elde edilen .90 ve üzerindeki değerler güvenirlik için yeterli olduğu için veri analizleri açısından araştırmada güvenirliğin yeterli düzeyde sağlandığı görülmüştür. Son olarak, araştırmacıların bir araya gelmesiyle uyumsuzluklar tartışılmış ve anlaşmazlıklar tamamıyla çözülmüştür. Böylece, araştırma verilerinin betimsel analizinde araştırmacılar arası uyum sağlanmıştır.

\section{Bulgular}

\section{MEB 2013 Okul Öncesi Eğitim Programının 21. Yüzyıl Becerileri Açısından Genel Görünümü}

Okul öncesi eğitim programında, okul öncesi eğitimin dayandığı temel ilkeler arasında “Çocukların hayal güçleri, yaratıcı ve eleştirel düşünme becerileri, iletişim kurma ve duygularını anlatabilme davranışları geliştirilmelidir." ifadesinin bulunduğu görülmektedir. Benzer şekilde, programının tanıtımının yapıldığı 
bölümde, "21. yüzyılın gereksinim duyduğu bireyi yetiştirmek" ifadesi programın temel özellikleri arasında yer almaktadır. Dolayısıyla, söz konusu ifadeler, programın 21. yüzyıl becerilerinin öğrencilere kazandırılması gerekliliğine vurgu yaptığını göstermektedir. 21. yüzyıl becerilerinin okul öncesi eğitim programında yer alma durumları Tablo 2' de özetlenmiştir.

Tablo 2. 21. Yüzyıl Becerilerinin Programdaki Dağılımı ve Örnek Alıntılar

\begin{tabular}{|c|c|c|c|c|}
\hline Beceriler & & f & $\%$ & Örnek Alıntılar (MEB, 2013a) \\
\hline \multirow[t]{7}{*}{$\begin{array}{l}\text { Öğrenme ve } \\
\text { Yenilik Becerileri }\end{array}$} & \multirow[t]{2}{*}{ İletişim } & \multirow[t]{2}{*}{55} & \multirow[t]{2}{*}{22,62} & $\begin{array}{l}\text { Çocukların okuma-yazma etkinliklerine ve kitaplara karşı olumlu } \\
\text { tutumlar geliştirmesini sağlamayı, dil ve iletişim becerilerini } \\
\text { desteklemeyi amaçlayan bu öğrenme merkezinin... (Okul öncesi } \\
\text { eğitim ortamları ve öğrenme merkezleri, Kitap merkezi, s. 40) }\end{array}$ \\
\hline & & & & $\begin{array}{l}\text { Dinlediklerini/izlediklerini çeşitli yollarla ifade eder (Dil gelişimi ile } \\
\text { ilgili kazanımlar, göstergeleri ve açıklamaları, Kazanım 8) }\end{array}$ \\
\hline & \multirow[t]{2}{*}{$\begin{array}{l}\text { Eleştirel Düşünme } \\
\text { ve Problem Çözme }\end{array}$} & \multirow[t]{2}{*}{39} & \multirow[t]{2}{*}{16,05} & $\begin{array}{l}\text { Problem durumlarına çözüm üretir (Bilişsel gelişim ile ilgili } \\
\text { kazanımlar, göstergeleri ve açıklamaları, Kazanım 19) }\end{array}$ \\
\hline & & & & $\begin{array}{l}\text { Problem durumlarına çözüm üretir (Bilişsel gelişimle ilgili } \\
\text { kazanımlar, göstergeleri ve açıklamaları, Kazanm 19) }\end{array}$ \\
\hline & \multirow[t]{2}{*}{$\begin{array}{l}\text { Yaratıcılik ve } \\
\text { Yenilik }\end{array}$} & \multirow[t]{2}{*}{15} & \multirow[t]{2}{*}{6,17} & $\begin{array}{l}\text { Yaratıcılığın geliştirilmesi ön plandadır (Okul öncesi eğitim } \\
\text { programının temel özellikleri, s. 16) }\end{array}$ \\
\hline & & & & $\begin{array}{l}\text { Kendini yaratıcı yollarla ifade eder (Sosyal ve duygusal gelişimle ilgili } \\
\text { kazanımlar, göstergeleri ve açıklamaları, Kazanım 3) }\end{array}$ \\
\hline & İşbirliği & 10 & 4,12 & $\begin{array}{l}\text { Öğrenme merkezleri çocukların bireysel gereksinimlerini karşılamak } \\
\text { amacıyla farklı ayırma materyalleri ile bölünmüş, küçük gruplar } \\
\text { hâlinde etkileşimde bulunacakları ve dikkatlerini yoğunlaştırarak } \\
\text { oynayabilecekleri öğrenme alanlarıdır (Programın temel özellikleri, } \\
\text { Öğrenme merkezleri önemlidir, s.16) }\end{array}$ \\
\hline
\end{tabular}

Yaşam ve Kariyer Girişimcilik ve Öz- $52 \quad 21,39$

Becerileri Öğrenme merkezleri önemlidir, s.16)

Sosyal ve

Kültürlerarası

Beceriler

Liderlik ve

Sorumluk

Esneklik ve Uyum

Üretkenlik ve Hesap

10

Verebilirlik
Güven ve bağımsız davranış geliştirme çalışmaları (Etkinlik çeşitleri ve açıklamaları, okuma yazmaya hazırlık etkinliği, s. 45)

Bir işi veya görevi başarmak için kendini güdüler (Sosyal ve duygusal gelişimle ilgili kazanımlar, göstergeleri ve açıklamaları, Kazanım 7)

Kültürel ve Evrensel Değerleri Dikkate Alır (Programın temel özellikleri s. 17)

Farklı kültürel özellikleri açıklar (Sosyal ve duygusal gelişimle ilgili kazanımlar, göstergeleri ve açıklamaları, Kazanım 9)

Öğretmen, her gün, günü değerlendirme zamanında bir sonraki günün eğitim sürecinde neler yapmak istediklerini çocuklara sorarak onların planlama sürecine de etkin katılımına özen göstermelidir (Günlük eğitim akışı, s. 53)

Kendine güvenir (Göstergeleri: ... Gerektiğinde liderliği üstlenir.) (Sosyal ve duygusal gelişimle ilgili, kazanımlar, göstergeleri ve açıklamaları, Kazanım 15)

Kendisinin ve başkalarının haklarını korur (Sosyal ve duygusal gelişimle ilgili kazanımlar, göstergeleri ve açıklamaları, Kazanım 6)

Sorumluluklarını yerine getirir (Sosyal ve duygusal gelişimle ilgili kazanımlar, göstergeleri ve açıklamaları, Kazanım 10)

Sembolik düşünmenin gelişimini destekleyen bu öğrenme merkezinde çocuğun farklı roller almasına, yeni keşiflerde bulunmasına, günlük yaşamdan olayları ve kişileri doğaçlama olarak canlandırmasına imkân sağlayan materyaller yer almaktadır (Okul öncesi eğitim ortamları ve öğrenme merkezleri, Dramatik oyun merkezi, s. 42)

Değişik ortamlardaki kurallara uyar (Sosyal ve duygusal gelişimle ilgili kazanımlar, göstergeleri ve açıklamaları, Kazanım 12)

,12 ... çocuğun çabalarına odaklanmalı, bu çabaları takdir etmeli, çocuğa iyi bir model olmalı ve yeni öğrenme fırsatları yaratmalıdır (Öğretmenin önemi, s.13)

Nesne/durum/olaya dikkatini verir (Göstergeleri: Dikkat edilmesi gereken nesne/durum olaya odaklanır...) (Bilişsel gelişimle ilgili kazanımlar, göstergeleri ve açılamaları, Kazanım 1) 


\begin{tabular}{llcll}
\hline $\begin{array}{l}\text { Bilgi, Medya ve } \\
\text { Teknoloji } \\
\text { Becerileri }\end{array}$ & $\begin{array}{l}\text { Bilgi ve Medya } \\
\text { Okur-yazarlığı }\end{array}$ & 2 & 0,82 & $\begin{array}{l}\text { Çocuklarla kullanmak üzere ise CD çalar, klasik müzik CD’leri, çocuk } \\
\text { şarkıları CD’leri ve müzik kitapları bulundurulmalıdır (Okul öncesi } \\
\text { eğitim ortamları ve öğrenme merkezleri, Müzik merkezi, s. 40) }\end{array}$ \\
\hline Toplam & & 243 & 100,00 & \\
\hline
\end{tabular}

Tablo 2 incelendiğinde, programın; yaratıcllık ve yenilik, iş birliği, esneklik ve uyum, üretkenlik ve hesap verebilirlik gibi bazı istisnalar dışında öğrenme ve yenilik becerileri ile yaşam ve kariyer becerilerini büyük oranda destekler nitelikte olduğu görülmüştür. Diğer yandan, bilgi, medya ve teknoloji becerilerinin programda yeterince ele alınmadığını ortaya çıkmıştır. Ayrıntılı olarak, programda, öğrenme ve yenilik becerilerinden en fazla iletişim ile eleştirel düşünme ve problem çözme becerilerine yer verilmiştir. Yaşam kariyer becerilerinden ise en fazla girişimcilik ve öz-yönetim ile sosyal ve kültürlerarası becerilere yer verilmiştir. Öte yandan, bilgi ve medya okur-yazarlığı, üretkenlik ve hesap verebilirlik ile iş birliği becerileri, programda en az yer alan becerilerdir. Örneğin, programda müzik öğrenme merkezinde, bilgi, medya ve teknoloji becerilerine ilişkin olarak yalnızca $\mathrm{CD}$, çalar, müzik CD’leri gibi ifadeler bulunmaktadır (Tablo 2).

\section{MEB 2013 Okul Öncesi Eğitim Programında 21. Yüzyıl Becerilerine Yönelik Kazanım ve Göstergeler}

21. yüzyıl becerilerinin kazanım ve göstergelerde yer alma durumları Tablo 3'te özetlenmiştir.

Tablo 3. 21. Yüzyıl Becerilerinin Kazanım ve Göstergeler Açısından Dă̆ılımı

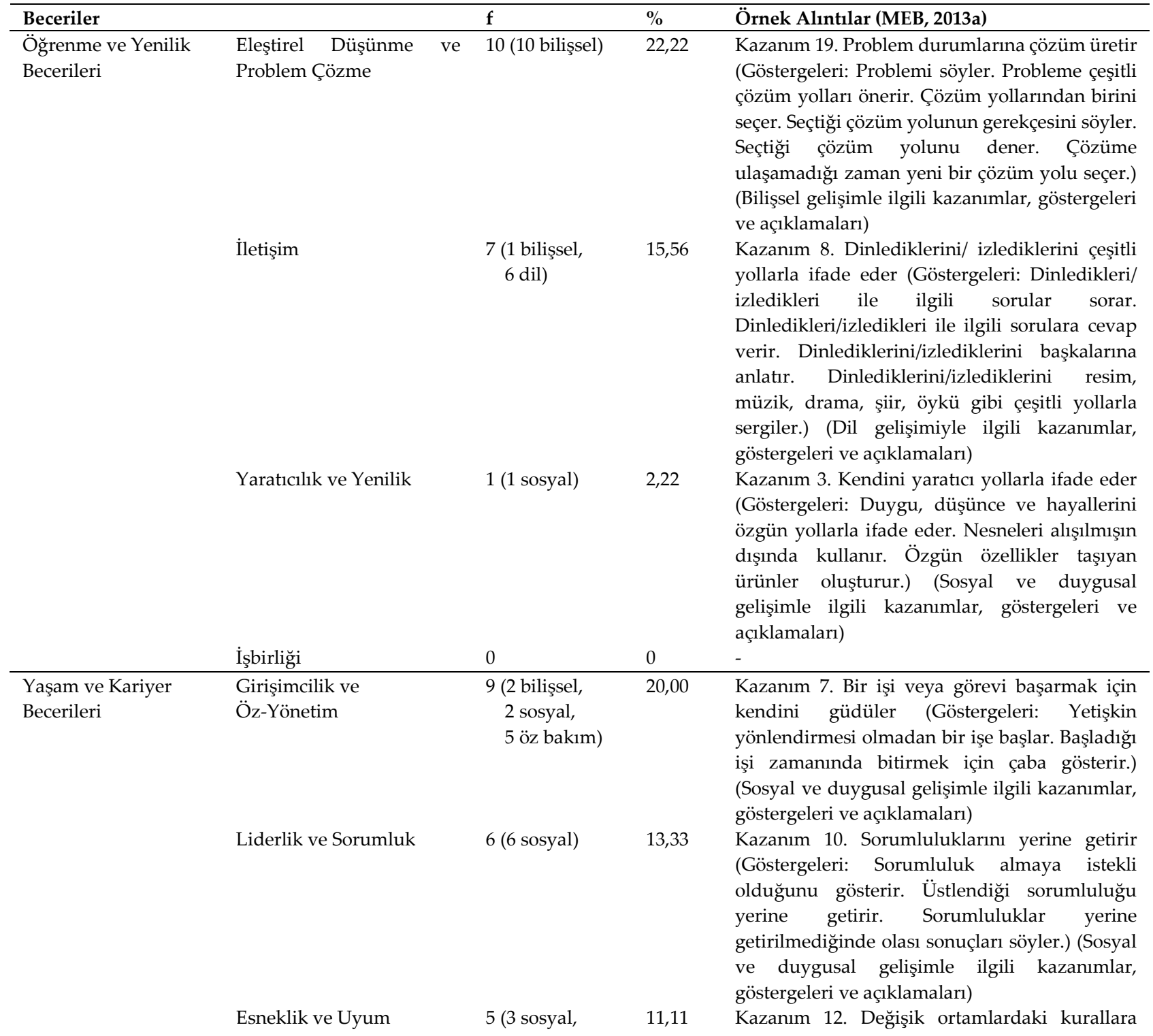


2 öz bakım)

Sosyal ve Kültürlerarası 4 (4 sosyal) Beceriler

Üretkenlik ve

Hesap Verebilirlik

3 (1 bilişsel, $\quad 6,67$
1 dil,
1 sosyal)

uyar (Göstergeleri: Değişik ortamlardaki kuralların belirlenmesinde düşüncesini söyler. Kuralların gerekli olduğunu söyler. İstekleri ile kurallar çeliştiğinde kurallara uygun davranır. Nezaket kurallarına uyar.) (Sosyal ve duygusal gelişimle ilgili kazanımlar, göstergeleri ve açıklamaları)

8,89 Kazanım 8. Farklılıklara sayg1 gösterir (Göstergeleri: Kendisinin farklı özellikleri olduğunu söyler. İnsanların farklı özellikleri olduğunu söyler. Etkinliklerde farklı özellikteki çocuklarla birlikte yer alır.) (Sosyal ve duygusal gelişimle ilgili kazanımlar, göstergeleri ve açıklamaları)

Kazanım 1. Nesne/durum/olaya dikkatini verir (Göstergeleri: Dikkat edilmesi gereken nesne/durum olaya odaklanır. Dikkatini çeken nesne/durum/olaya yönelik sorular sorar. Dikkatini çeken nesne/durum/olay1 ayrıntılarıyla açıklar.) (Bilişsel gelişimle ilgili kazanımlar, göstergeleri ve açıklamaları)

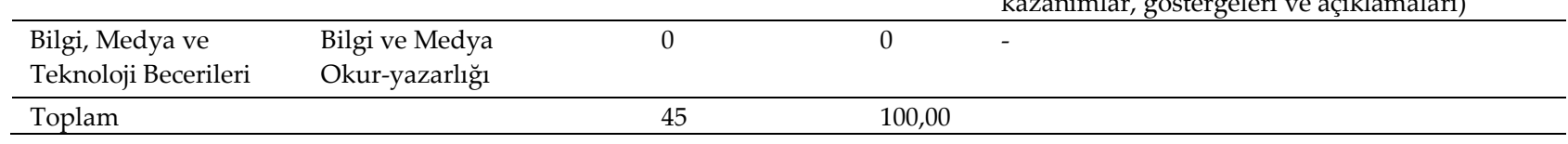

Tablo 3'te görüldüğü gibi, okul öncesi eğitim programında en fazla eleştirel düşünme ve problem çözme ile girişimcilik ve öz-yönetim becerilerine yönelik kazanım ve gösterge bulunmaktadır. Diğer yandan, programda iş birliği becerisi ile bilgi, medya ve teknoloji becerileriyle ilgili kazanım yoktur. Öğrenme ve yenilik becerileri en çok bilişsel gelişimle ilgili kazanım ve göstergelerde; yaşam ve kariyer becerileri ise sosyal ve duygusal gelişimle ilgili kazanım ve göstergelerde yer almaktadır.

\section{Etkinlik Kitabının 21. Yüzyıl Becerileri Açısından Genel Görünümü}

21. yüzyıl becerilerinin etkinlik kitabında yer alma durumları Tablo 4'te özetlenmiştir.

Tablo 4. 21. Yüzyıl Becerilerinin Etkinlik Kitabındaki Dağılımı ve Örnek Alıntılar

\begin{tabular}{|c|c|c|c|c|}
\hline Beceriler & & $\mathrm{f}$ & $\%$ & Örnek Alıntılar (MEB, 2013b) \\
\hline \multirow[t]{4}{*}{$\begin{array}{l}\text { Öğrenme ve } \\
\text { Yenilik } \\
\text { Becerileri }\end{array}$} & $\begin{array}{l}\text { Eleştirel Düşünme } \\
\text { ve Problem Çözme }\end{array}$ & 57 & 29,84 & $\begin{array}{l}\text { Buz Üzerinde...: Çocuklara, iklim değişikliğinden dolayı kutup ayılarının } \\
\text { evlerinin (iglo) bulunduğu buz dağının eridiği söylenir. Ayılar eriyen buzlardan } \\
\text { dolayı evlerine ulaşamamaktadırlar. Ayıların bu sorunu nasıl çözebileceği } \\
\text { tartışılır. Her bir çocuk kutup ayısı rolüne girerek oyuna katılır. (Etkinlik 26, s.62) }\end{array}$ \\
\hline & İletişim & 47 & 24,61 & $\begin{array}{l}\text { Olumlu Olumsuz: Daha sonra çocuklar çektikleri karttaki nesneyi bedenleriyle } \\
\text { başka sözleri kullanarak, çizerek gibi farklı yollarla eşlerine anlatırlar,... (Etkinlik } \\
\text { 10, s.30) }\end{array}$ \\
\hline & $\begin{array}{l}\text { Yaratıcılık ve } \\
\text { Yenilik }\end{array}$ & 23 & 12,04 & $\begin{array}{l}\text { Fotoğraflarla Atatürk: Masalardan birine farklı renkte kartonlar, diğerine farklı } \\
\text { büyüklükte kutular konur. Ayrıca her iki masada da yapıştırıcılar, boyalar, farklı } \\
\text { ip ve kumaş parçaları, kurdeleler vb vardır. Her grup bu fotoğrafları ve } \\
\text { materyalleri kullanarak istedikleri çalışmayı yaparlar. Çalışmalar sınıfta sergilenir. } \\
\text { (Etkinlik 14, s. 38) }\end{array}$ \\
\hline & İşbirliği & 13 & 6,82 & $\begin{array}{l}\text { Bizim Çizgilerimiz: Çocuklar iki grup şeklinde kâğıtların etrafına otururlar. Her } \\
\text { çocuk istediği bir renkte keçeli boya kalemi alır. Çocuklardan biri kâğıdın üzerine } \\
\text { dilediği uzunlukta, eğik, düz, yuvarlak vb. bir çizgi çizer. Diğer çocuklar da sıra ile } \\
\text { çizginin kaldığı yerden çizmeye devam ederler (Etkinlik 13, s.36) }\end{array}$ \\
\hline \multirow[t]{3}{*}{$\begin{array}{l}\text { Yaşam ve } \\
\text { Kariyer } \\
\text { Becerileri }\end{array}$} & $\begin{array}{l}\text { Üretkenlik ve } \\
\text { Hesap Verebilirlik }\end{array}$ & 23 & 12,05 & $\begin{array}{l}\text { Kartopu Oynuyoruz: Çocuklar sırayla "kartopunu yerden al" ve "kardan adama } \\
\text { at" yönergeleri ile kartoplarını daha önceden duvara asılmış olan kardan adam } \\
\text { resmine atarlar. (Etkinlik 30, s.70) }\end{array}$ \\
\hline & Esneklik ve Uyum & 7 & 3,66 & $\begin{array}{l}\text { Müze Bizi Bekler: Çocuklarla birlikte müze gezilirken uyulacak kurallar belirlenir. } \\
\text { (Etkinlik 20, s.50) }\end{array}$ \\
\hline & $\begin{array}{l}\text { Girişimcilik ve Öz- } \\
\text { Yönetim }\end{array}$ & 7 & 3,66 & $\begin{array}{l}\text { Terzi Olsam: Çocuklar konuşulan tüm soruları gözden geçirirler, terziye } \\
\text { gidildiğinde neler öğrenmek istedikleri konusunda plan yaparlar.(Etkinlik } 40 \text {, s. }\end{array}$ \\
\hline
\end{tabular}




\begin{tabular}{llcll} 
& $\begin{array}{l}\text { Sosyal ve } \\
\text { Kültürlerarası } \\
\text { Beceriler }\end{array}$ & 7 & 3,66 & $\begin{array}{l}\text { Bu Gölge Kimin?: Çocuklar kendi aralarında birbirlerinin benzer olan ve olmayan } \\
\text { özellikleri hakkında konuşurlar. (Etkinlik 24, s.58) }\end{array}$ \\
$\begin{array}{l}\text { Liderlik ve } \\
\text { Sorumluk }\end{array}$ & 7 & 3,66 & $\begin{array}{l}\text { Fotoğraflarla Atatürk: Kazanım 11. Atatürk ile ilgili etkinliklerde sorumluluk alır. } \\
\text { (Göstergeleri: Atatürk ile ilgili etkinliklere katılır. Atatürk ile ilgili duygu ve } \\
\text { düşüncelerini farklı etkinliklerle ifade eder.) Etkinlik 14, s.38.) }\end{array}$ \\
\hline $\begin{array}{l}\text { Bilgi, Medya ve } \\
\begin{array}{l}\text { Teknoloji } \\
\text { Becerileri }\end{array}\end{array}$ & $\begin{array}{l}\text { Bilgi ve Medya } \\
\text { Okur-yazarlığ }\end{array}$ & 0 & 0 & - \\
\hline Toplam & & & \\
\hline
\end{tabular}

Tablo 4 incelendiğinde, etkinlik kitabında, en fazla eleştirel düşünme ve problem çözme ile iletişim becerilerine yönelik örnek etkinliğin olduğu görülmektedir. Örnek etkinliklerde diğer becerilere göre daha az yer alan beceriler ise, esneklik ve uyum, girişimcilik ve öz-yönetim, sosyal ve kültürlerarası beceriler ile liderlik ve sorumluluktur. Etkinlik kitabında, bilgi, medya ve teknoloji becerilerine ilişkin örnek etkinlik bulunmamaktadır.

Mevcut araştırmadan elde edilen bulgular ve yukarıda yapılan açıklamalardan hareketle, okul öncesi eğitim programı, kazanım ve göstergeler ile etkinlik kitabı üç ana beceri alanına (öğrenme ve yenilik, yaşam ve kariyer, bilgi, medya ve teknoloji becerileri) göre değerlendirildiğinde, öğrenme ve yenilik (\% 48.96) ile yaşam ve kariyer (\% 50.22) becerilerinin birbirine yakın oranlarda programda yer aldığı söylenebilir. Diğer yandan, programda yaşam ve kariyer becerileri (\% 60; öğrenme ve yenilik becerileri \% 40) ile ilgili daha fazla kazanım ve göstergenin bulunduğu görülmektedir. Etkinlik kitabında ise, büyük oranda öğrenme ve yenilik becerilerine (\% 73.31; yaşam ve kariyer becerileri \% 26.69) yönelik örnek etkinliklerin sunulduğu ifade edilebilir. Bilgi, medya ve teknoloji becerilerine ilişkin olarak, söz konusu becerilerin okul öncesi eğitim programında çok az bulunduğu (\% 0.82), kazanım ve göstergeler ile etkinlik kitabında ise hiç bulunmadığı anlaşılmaktadır.

\section{Tartışma}

Araştırmadan elde edilen bulgular, okul öncesi eğitim programının ve etkinlik kitabının 21. yüzyıl becerilerinin kazandırılmasını destekler nitelikte olduğunu göstermiştir. Söz konusu bulgular, okul öncesi eğitim programının özellikle öğrenme ve düşünme yolları ile ilgili beceriler bakımından öğrencileri 21. yüzyıla hazırladığını gösteren Koçin ve Tuğluk'un (2020) araştırma bulgularıyla tutarlılık göstermektedir. Bu durum, söz konusu becerilerden birçoğunun aslında yeni ortaya çıkmış beceriler olmayıp, uzun yıllar boyunca çocuklara kazandırılması gereken beceriler olduğuna işaret etmektedir. Nitekim 21. yüzyıl becerileri olarak ifade edilen becerilerin bireylere kazandırılmasına yönelik anlayışın antik çağlara kadar dayandığı görülmektedir (Paul, Elder ve Bartell, 1997). Örneğin, Sokrates ve Platon, iletişim becerileri ve eleştirel düşüncenin önemini vurgularken, Aristoteles, iş birliğinin ve başkalarıyla ortaklaşa çalışmanın önemini belirtmiş; bireysel ya da ortak yaratıcı icatlara duyulan ihtiyacı ortaya çıkarmıştır (Brenegar, 2004). Bu nedenle, okul öncesi eğitim programında ve etkinlik kitabında eleştirel düşünme ve problem çözme gibi becerilere yer verilmesi, bu becerilerin yeni olmasına değil, 21. yüzyılın gereksinim duyduğu bireyi yetiştirmek için söz konusu becerilere yeniden ihtiyaç duyulmasına bağlanabilir (Copeland, 2005; Johnson ve Reed, 2008). Ayrıca, mevcut program, halihazırda birçok beceriyi içermesi nedeniyle çok büyük düzenleme ve ekleme gerektirmemektedir. Nitekim Dede'ye (2010) göre, uygulanan programların halihazırda kalabalık olduğu düşünüldügünde, 21. yüzyll becerilerine yer açmak için programdan neyin feda edileceğini belirlemek ve bunun nedenini açıklamak bir sorun teşkil etmektedir. Oysaki araştırma bulguları, 21. yüzyıl becerilerinin okul öncesi eğitim için hiç de yabancı beceriler olmadığını göstermiş ve bu becerilerin programla kolayca bütünleştirebilir beceriler olduğu gerçeğini ortaya koymuştur (Jacobson-Lundeberg, 2016).

$\mathrm{Bu}$ araştırmada elde edilen bulgular ayrıca, diğer becerilere oranla okul öncesi eğitim programında iletişim becerileri ile girişimcilik ve öz-yönetim becerilerine daha çok yer verildiği göstermiştir. Araştırmanın bu bulgusu, programın okul öncesi eğitimin temel ilkeleri ve okul öncesi dönemin önemi bölümlerinde 
çocukların çevreleriyle etkili iletişim kurmalarının ve bağımsız bireyler olmalarının desteklenmesine yapılan vurgu ile açıklanabilir (MEB, 2013a). Nitekim dilin iletişim kurma aracı olduğu düşünüldügünde, etkili bir iletişimde dil kullanımının oldukça önemli olduğu söylenebilir. Programda dil gelişimine geniş bir yer ayrılması, çocukların iletişim becerilerini geliştirmelerine programın verdiği önemi ortaya koymaktadır. Benzer bir öneme, kazanımlar ve örnek etkinliklerin yer aldığı etkinlik kitabında da rastlamak mümkündür. İletişim becerileriyle ilgili kazanımların neredeyse tamamı dil gelişimiyle ilgili kazanımlar arasındadır. Etkinlik kitabındaki iletişim becerilerinin sıklıkla ele alınması ise, diğer becerilerin daha etkili bir biçimde kazandırılmasına olanak sağlamaktadır. Nitekim dilin, düşünme, problem çözme, eleştirel düşünme, planlama gibi bilişsel süreçlere kaynaklık ettiği ve iletişim becerilerinin stres yönetimi ve risk alma gibi daha karmaşık becerilerin kazanımına zemin hazırladığı bilinen bir gerçektir (Jacobson-Lundeberg, 2016). İletişim becerilerine benzer bir biçimde, girişimcilik ve öz-yönetim becerileri de programda sıklıkla yer alan becerilerdir. Okul öncesi eğitimin ilkeleri bölümünden başlayarak programın genelinde vurgulanan, girişimcilik ve öz-yönetim becerileri, öz bakım becerilerine yönelik olan kazanımlarda kendini ağırlıklı olarak göstermektedir. Programda bu becerilere sıklıkla yer verilmesi, okul öncesi dönemde çocukların hem okul hem de günlük yaşamlarında kendilerine güvenen ve bağımsız davranış geliştirebilen bireyler olarak yetişmelerinin gerekliliğine işaret etmektedir (MEB, 2013a).

Diğer taraftan, araştırmadan elde edilen bulgular, iş birliği, üretkenlik ve hesap verebilirlik ile bilgi, medya ve teknoloji becerilerinin hem okul öncesi eğitim programının genelinde hem de kazanım ve göstergelerde en az vurgulanan beceriler olduğunu göstermiştir. İş birliği ile üretkenlik ve hesap verebilirlik becerilerine yapılan vurgunun azlığı, bu becerilerin etkinlik kitabında örnek etkinlikler aracılı̆̆ıla dolaylı öğretimine bağlı olarak açıklanabilir. Oysaki çocukların 21. yüzyıl becerilerini etkili bir biçimde kazanabilmeleri için bu becerilerin açık bir biçimde ve doğrudan okul öncesi eğitim programında vurgulanması gerekmektedir. Nitekim Saavedra ve Opfer (2012b)'e göre, öğrencilere 21. yüzyıl becerilerinin açıkça öğretilmemesi, onların bu becerileri geliştirmelerinin önünde bir engel teşkil etmektedir.

Ayrıca, bilgi tabanlı ekonomilerde gün geçtikçe önemi ve etkililiği artan bu becerilere programda yeterince yer verilmemesi, 21. yüzyılda gerek günlük yaşamda gerekse iş yaşamında başarının elde edilmesini zorlaştıracaktır (Rotherham ve Willingham, 2009). Her ne kadar okul öncesi eğitimi programının tanıtımı bölümünde “... Bu programda 21. yüzyılın gereksinim duyduğu bireyi yetiştirmek, ulusal özellik ve gereksinimleri karşılamak amacıyla farklı öğrenme kuram ve modellerindeki çocuk merkezli uygulamalardan yararlanılarak bir senteze ulaşılmıştır." ifadesiyle programın temel özellikleri arasında, 21. yüzyılda başarıyı elde edebilecek bireylerin yetiştirilmesi yer alsa da, programın ve etkinlik kitabının özellikle bilgi, medya ve teknoloji becerilerini kazandırmada yetersiz kaldığı görülmektedir. Bu bulgu, okul öncesi eğitim programında, 21. yüzyıl becerilerinde vurgulanan teknoloji ve medya okuryazarlığ ile ilgili kazanımlara pek rastlanmadığına ilişkin (Koçin ve Tuğluk, 2020; Tuğluk ve Özkan, 2019) araştırmalardan elde edilen bulgularla tutarlıdır. Teknoloji ve medya araçlarının küçük yaş çocukları için kullanımının gelişimsel olarak uygunluğu tartışmalı bir konu olmasına rağmen (Finnegan ve Austin 2002; Plowman, McPake ve Stephen, 2010), teknolojiyle çevrelenmiş bir dünyaya gelen ve dijital yerliler (Prensky, 2001) olarak tanımlanan günümüz çocuklarının gerek eğitim, gerekse günlük yaşamlarında sürekli maruz kaldıkları medya ve teknoloji konusunda ihtiyaçlarının göz ardı edilmesi doğru bir yaklaşım olmayacaktır. Çocukların bilgi ve medya okuryazarlığı ile bilgi ve iletişim teknolojileri okuryazarlığı geliştirmeleri, onların bilgi çağı olarak nitelendirilen 21. yüzyılda etkili bir biçimde yaşamalarına ve öğrenmelerine katkı sağlayacak (Parette, Quesenberry ve Blum, 2010; Voogt ve Roblin, 2010) ve bilgi, medya ve teknolojinin erişimine ve kullanımına ilişkin etik ve yasal konularda temel bir anlayış kazanmalarına yardımcı olacaktır (P21-A Network of Battelle for Kids, 2019c).

\section{Sonuç ve Öneriler}

Araştırmadan elde edilen ve yukarıda tartışılan bulgulardan hareketle, 2013 yılından itibaren uygulanan okul öncesi eğitim programının erken çocukluk döneminde 21. yüzyıl becerilerinin kazandırılmasına yönelik önemli bir potansiyel taşıdığı söylenebilir. Özellikle, eleştirel düşünme ve problem çözme, iletişim, girişimcilik 
ve öz-yönetim becerilerine programın genelinde, kazanım ve göstergelerde ve etkinlik kitabında sıklıkla yer verilmesi, programın ve etkinlik kitabının 21. yüzyıl becerileri açısından zengin bir kaynak olduğuna işaret etmektedir.

Diğer yandan, yaratıcılık ve yenilik, esneklik ve uyum, sosyal ve kültürlerarası beceriler ile liderlik ve sorumluluk becerilerinin program, kazanım ve göstergeler ile etkinlik kitabında görece daha az yer aldığı göz önüne alınarak, 21. yüzyıl becerilerinin programda ve etkinlik kitabında daha dengeli bir dağılımı yapılmalıdır. Benzer şekilde, iş birliği ile üretkenlik ve hesap verebilirlik becerilerinin etkinlik kitabında örnek etkinlikler aracılığıyla ele alınmasına rağmen hem programın genelinde hem de kazanım ve göstergelerde en az vurgulanan beceriler olması, bu becerilerin açık bir biçimde ve doğrudan okul öncesi eğitim programında vurgulanmasını gerektirmektedir. Bu nedenle, program, iş birliği ile üretkenlik ve hesap verebilirlik becerilerine ilişkin kazanım ve göstergeler içerecek şekilde düzenlenmelidir. Bunlara ek olarak, bilgi, medya ve teknoloji becerilerinin programda açıkça yer alması gerekmektedir. Nitekim çocukların gelişimsel özellikleri dikkate alınarak bilgi ve iletişim teknolojilerinin okul öncesi eğitimiyle etkili bir biçimde bütünleştirilebilmektedir (National Association for Education of Young Children [NAEYC], 2012; Van Laar, Van Deursen, Van Dijk ve De Haan, 2017). Bu bağlamda, çocukların günlük yaşamlarında halihazırda var olan bilgi ve iletişim teknolojilerinin kullanımının eğitim programı aracılığıyla gelişimsel özelliklerine uygun bir biçimde planlı ve kontrollü olarak çocuklara sunulması, 21. yüzyıl bireyleri olarak yetişmeleri ve bilgi, medya ve teknoloji okuryazarlığı konusunda bir anlayış geliştirmeleri açısından önemlidir. Örneğin, programa bilgi okuryazarlığıyla ilgili "Bilgiye çeşitli kaynaklardan erişir." ya da "Bilgiyi eleştirel bir şekilde değerlendirir." biçimindeki kazanımlar eklenerek çocukların araştırma yapmalarına, bilgiye erişmek için çeşitli kaynakları kullanmalarına ve eriştikleri bilgileri değerlendirmelerine imkan sağlanabilir (P21-A Network of Battelle for Kids, 2019c, s. 16).

Okul öncesi eğitim programında ihmal edilen becerilerin kazandırılmasına yönelik benimsenecek yaklaşımlardan bir diğeri, programdaki öğrenme merkezlerinin kullanımı olabilir. Diğer bir ifadeyle, 21. yüzyıl becerilerinin kazandırılmasında öğrenme merkezlerinden (örneğin, blok merkezi, fen merkezi, sanat merkezi) yararlanılabilir. Örneğin, yemek sırasında çocukların makinelerin ne işe yaradığı konusundaki konuşmalarına tanık olan bir öğretmenin, çocukların çeşitli makinelerle ilgili tasarım süreçlerini deneyimleyebilecekleri etkinlikleri, hemen hemen her sinıfta bulunan blok merkezi aracılığıyla gerçekleştirebilmesi, bu becerilerin kazandırılmasında erken çocukluk eğitim ortamlarının zenginliğine işaret etmektedir (Lindeman ve Anderson, 2015). Böyle bir etkinlikte, çeşitli disiplinlerin (teknoloji, matematik, sanat, matematik ve fen) bütünleştirilmesiyle çocukların, farklı becerileri (yaratıcılık, iş birliği, eleştirel düşünme ve problem çözme) kazanmalarına olanak sağlanabilir.

Okul öncesi eğitim programının yanı sıra etkinlik kitabındaki öğrenme ve yenilik becerilerinin ağırlığı göz önüne alındığında, etkinlik kitabında bütün beceriler açısından bir dengenin sağlanması yararlı olacaktır. Etkinlik kitabı, öğretmenlere rehber olması amacıyla hazırlanmış bir kaynaktır (MEB, 2013b). Başka bir ifadeyle, etkinlik kitabında, eğitim programının nasıl uygulanacağı, kazanımlar temel alınarak etkinliklerin nasıl hazırlanacağı ve değerlendirmelerin nasıl yapılacağı, aile katılım çalışmaları ve özel gereksinimli çocuklar için öğrenme süreçlerinin nasıl uyarlanacağına yönelik örnekler yer almaktadır. Esasen, bu kaynak, programın pratikteki bir yansımasıdır çünkü bu kitapta sunulan etkinlikler öğretmenlerin planlayacakları diğer etkinliklere yol gösterici olacaktır. Dolayısıyla, etkinlik kitabı güncellenerek yaşam ve kariyer ile bilgi, medya ve teknoloji becerilerine ilişkin yeterli örnek etkinlikleri içerecek şekilde düzenlenebilir.

\section{Yazar(lar)ın Beyanı}

Araştırmacıların katkı oranı beyanı: Araştırmanın alanyazın taraması, verilerin toplanması, analizi, raporlanması ve yorumlanması süreçlerinde yazarlar birlikte çalışmıştır. Araştırmada ele alınan konu itibariyle, birinci yazar verilerin yorumlanması aşamasında daha etkin bir rol üstlenmiştir.

Etik Kurul Kararı: Araştırmada benimsenen doküman analizi kapsamında bir okul öncesi eğitim programı ve bu programla ilgili yardımcı bir kaynak incelenmiştir. Bu nedenle araştırma etik kurul izni gerektirmemektedir. 
Çatışma beyanı: Araştırmanın yazarları arasında herhangi bir çıkar çatışması bulunmamaktadır. Ayrıca, yazarlar, diğer kişi, kurum ya da kuruluşla herhangi bir çıkar çatışması olmadığııı beyan eder.

Destek ve teşekkür: Bu araştırmanın gerçekleştirilmesi için herhangi bir kurum ya da kuruluştan destek alınmamıştır.

\section{Kaynaklar}

Ananiadou, K. ve Claro, M. (2009). 21st century skills and competences for new millennium learners in OECD countries, OECD Education Working Papers (No. 41). Paris: OECD Publishing. http://dx.doi.org/10.1787/218525261154

Ata-Aktürk, A., Demircan, H. Ö., Şenyurt, E. ve Çetin, M. (2017). Turkish early childhood education curriculum from the perspective of stem education: A document analysis. Journal of Turkish Science Education, 14(4), 16-34.

Bal, M. (2018). Türkçe dersinin 21. yüzyıl becerileri açısından incelenmesi. Turkish Studies, 13(4), 49-64.

Belet-Boyacı, Ş. ve Güner-Özer, M. (2019). Öğrenmenin geleceği: 21. yüzyıl becerileri perspektifiyle Türkçe dersi öğretim programları. Anadolu Journal of Educational Sciences International, 9(2), 708-738.

Binkley, M., Erstad, O., Herman, J., Raizen, S., Ripley, M. ve Rumble, M. (2010). Draft white paper 1: Defining 21st century skills. 10 Ocak 2021 tarihinde http://www.ericlondaits.com.ar/oei_ibertic/sites/default/ files/biblioteca/24_defining-21st-century-skills.pdf adresinden erişildi.

Binkley, M., Erstad, O., Herman, J., Raizen, S., Ripley, M., Miller-Ricci M. ve Rumble, M. (2012). Defining twenty-first century skills. P. Griffin, B. McGaw ve E. Care (Ed.) Assessment and teaching of 21st century skills (s. 17-66) içinde. Dordrecht: Springer.

Bowen, G. A. (2009). Document analysis as a qualitative research method. Qualitative Research Journal, 9(2), 2740.

Brenegar, E. (2004). Aristotle on civic leadership. 10 Ocak 2021 tarihinde http://edbrenegar.typepad.com/leading_questions /2004/10/aristotle_on_ci.html adresinden erişildi.

Care, E., Kim, H., Vista, A. ve Anderson, K. (2018). 10 Ocak 2021 tarihinde Education system alignment for 21st century skills: Focus on assessment. https://files.eric.ed.gov/fulltext/ED592779.pdf adresinden erişildi.

Castells, M. (2010). The rise of the network society. The Information age: Economy, society, and culture. Volume 1. (2. bs ). Oxford, UK: Wiley-Blackwell.

Chu, S. K. W., Reynolds, R. B., Tavares, N. J., Notari, M. ve Lee, C. W. Y. (2017). 21st century skills development through inquiry-based learning. Singapore: Springer.

Copeland, M. (2005). Socratic circles: Fostering critical and creative thinking in middle and high school. Portland, ME: Stenhouse Publishers.

Dede, C. (2010). Comparing frameworks for 21st century skills. J. Bellanca ve R. Brandt (Ed.) 21st century skills: Rethinking how students learn (s. 51-77) içinde. Bloomington, IN: Solution Tree Press.

Finnegan, C. ve Austin, N. J. (2002). Developmentally appropriate technology for young children. Information Technology in Childhood Education Annual, 1, 87-102.

Griffin, P., Care, E. ve McGaw, B. (2012). The changing role of education and schools. P. Griffin, B. McGaw, ve E. Care (Ed.) Assessment and teaching of 21st century skills (s. 1-15) içinde. Dordrecht: Springer.

Gullo, D. F. (2005). Understanding assessment and evaluation in early childhood education. New York, NY: Teachers College Press.

Helm, J. H. ve Katz, L. G. (2001). Young investigators: The project approach in the early years. New York, NY: Teachers College Press. 
Hinitz, B. F. (2013). Introduction. B.F. Hinitz (Ed.) The hidden history of early childhood education (s.1-4) içinde. New York, NY: Routledge.

Huber, R. ve Bates, C. C. (2016). Are you (P)interested in 21st century teaching and learning? Young Children, 71(3), 25-29.

Jacobson-Lundeberg, V. (2016). Pedagogical implementation of 21st century skills. Educational Leadership and Administration: Teaching and Program Development, 27, 82-100.

Johnson, T. W. ve Reed. R. F. (2008). Philosophical documents in education (3rd ed). Boston: Pearson.

Kaymakcı, S. (2017). Türkiye'de tarih öğretiminin yönelimi üzerine bir değerlendirme. Kastamonu Eğitim Dergisi, 25(6), 2153-2172.

Koçin, B. ve Tuğluk, M. N. (2020). 2013 Okul öncesi eğitim programının 21. yüzyıl becerileri açısından incelenmesi. Ulakbilge, 49, 621-649.

Kostelnik, M. J., Soderman, A. K., Whiren, A. P. ve Rupiper, M.L. (2019). Developmentally appropriate curriculum: Best practices in early childhood education (7. bs.). New York, NY: Pearson.

Lascarides, V. C ve Hinitz, B. F. (2000). History of early childhood education. New York, NY: Falmer Press.

Larson, L. C. ve Miller, T. N. (2011). 21st century skills: Prepare students for the future. Kappa Delta Pi Record, 47(3), 121-123. https://doi.org/10.1080/00228958.2011.10516575

Levy, F. ve Murnane, R. J. (2004). Education and the changing job market. Educational Leadership, 62(2), 80-83.

Lindeman, K. W. ve Anderson, E. M. (2015). Using blocks to develop 21st century skills. YC: Young Children, 70(1), 36-43.

Martin, M. O., Mullis, I. V. S., Foy, P. ve Hooper, M. (2016). TIMSS 2015 international results in science. 10 Ocak 2021 tarihinde http://imssandpirls.bc.edu/timss2015/internationalresults/wpcontent/uploads/ filebase/full\%20pdfs/T15-International-Results-in-Science-Grade-8.pdf adresinden erişildi.

Medel-Añonuevo, C., Ohsako, T. ve Mauch, W. (2001). Revisiting lifelong learning for the 21st century. Hamburg: UNESCO Institute for Education.

Miles, M. B. ve Huberman, A. M. (2002). The qualitative researcher's companion. California, CA: Sage Publications.

Milli Eğitim Bakanlığı [MEB] (2006). Okul öncesi eğitimi programı. 10 Ocak 2021 tarihinde https://tegm.meb.gov.tr/dosya/okuloncesi/ooproram.pdf adresinden erişildi.

Milli Eğitim Bakanlığı [MEB] (2013a). Okul öncesi eğitimi programı. 10 Ocak 2021 tarihinde https://tegm.meb.gov.tr/dosya/okuloncesi/ooproram.pdf adresinden erişildi.

Milli Eğitim Bakanlığı [MEB] (2013b). Okul öncesi eğitim programı - 2013: Etkinlik kitabı. 10 Ocak 2021 tarihinde http://anaokulu.cu.edu.tr/_/file/OOEP_2013_Etkinlik_Kitabi.pdf adresinde erişildi.

Mullis, I. V. S., Martin, M. O., Foy, P. ve Hooper, M. (2016). TIMSS 2015 international results in mathematics. 10 Ocak 2021 tarihinde https://timssandpirls.bc.edu/timss2015/international-results/ adresinden erişildi.

National Association for the Education of Young Children [NAEYC]. (2012). Technology and interactive media as tools in early childhood programs serving children from birth through age 8. 10 Ocak 2021 tarihinde https://www.naeyc.org/sites/default/files/globallyshared/downloads/PDFs/resources/topics/PS_technolo gy_WEB.pdf adresinden erişildi.

Organisation for Economic Co-Operation and Development [OECD] (2009). Creating effective teaching and learning environments: First results from TALIS. Paris, OECD Publishing. 10 Ocak 2021 tarihinde http://www.oecd.org/education/school/43023606.pdf adresinden erişildi.

Osler, A. ve Vincent, K. (2002). Citizenship and the challenge of global education. Stoke-on-Trent, Trentham: 
Trentham Books.

Otuz, B., Görkaş-Kayabaşı, B. ve Ekici, G. (2018). 2017 Sosyal Bilgiler Dersi Öğretim Programı Beceri ve Değerlerinin Anahtar Yetkinlikler Açısından Analizi. Kuramsal Eğitimbilim Dergisi, 11(4), $944-972$.

P21-A Network of Battelle for Kids (2019a). Framework for 21st century learning definitions. 10 Ocak 2021 tarihinde http://static.battelleforkids.org/documents/p21/P21_Framework_DefinitionsBFK adresinden erişildi.

P21-A Network of Battelle for Kids (2019b). 21st century learning for early childhood guide. 10 Ocak 2021 tarihinde http://static.battelleforkids.org/documents/p21/P21EarlyChildhoodGuide.pdf adresinden erişildi.

P21-A Network of Battelle for Kids (2019c). 21st century skills early learning framework. 10 Ocak 2021 tarihinde http://static.battelleforkids.org/documents/p21/P21Early ChildhoodFramework.pdf adresinden erişildi.

Parette, H. P., Quesenberry, A. C. ve Blum, C. (2010). Missing the boat with technology usage in early childhood settings: A 21st century view of developmentally appropriate practice. Early Childhood Education Journal, 37(5), 335-343.

Paul, R., Elder, L. ve Bartell, T. (1997). A brief history of critical thinking. 10 Ocak 2021 tarihinde http://www.criticalthinking.org/pages/a-brief-history-of-the-idea-of-criticalthinking adresinden erişildi.

Plowman, L., McPake, J. ve Stephen, C. (2010). The technologisation of childhood? Young children and technology in the home. Children E Society, 24(1), 63-74.

Prensky, M. (2001). Digital natives, digital immigrants. On the Horizon, 9(5), 1-6.

Ramey, M. D.(2016). 21st Century teaching and learning. Young Children, 71(3), 6-7.

Rotherham, A. J. ve Willingham, D. (2009). Twenty-first-century skills: The challenges ahead. Educational Leadership, 67(1), 16-21.

Saavedra, A. R. (2012). Dry to dynamic civic education curricula. D. Campbell, M. Levinson ve F. Hess (Ed.), Making civics count: Citizenship education for a new generation (s. 135-159) içinde. Cambridge, MA: Harvard Education Press.

Saavedra, A. R. ve Opfer, V. D. (2012a). Learning 21st-century skills requires 21st-century teaching. Phi Delta Kappan, 94(2), 8-13. https://doi.org/10.1177/003172171209400203

Saavedra, A. R.ve Opfer, V. D. (2012b). Teaching and learning 21st century skills: Lessons from the learning sciences. A Global Cities Education Network Report. New York, Asia Society. 10 Ocak 2021 tarihinde https://ugeb.pw/05-00-43.pdf adresinden erişildi.

Schleicher, A. (2019). PISA 2018: Insights and interpretations. Paris: OECD Publishing.

Schleicher, A. (2012). Building a high-quality teaching profession. Lessons from around the world. Educational Studies, (1), 74-92.

Silva, E. (2009). Measuring skills for 21st-century learning. Phi Delta Kappan, 90(9), 630-634.

Suna, H. E., Tanberkan, H. ve Ozer, M. (2020). Changes in literacy of students in Turkey by years and school types: Performance of students in PISA applications. Journal of Measurement and Evaluation in Education and Psychology, 11(1), 76-97. https://doi.org/10.21031/epod.702191

Sylva, K., Pastori, G., Lerkkanen, M. K., Ereky-Stevens, K. ve Slot, P. (2016). Integrative report on a culturesensitive quality and curriculum framework. 10 Ocak 2021 tarihinde https://ececcare.org/f ileadmin/careproject/Publications/reports/D2_4_Integrative_Report_wp2_FINAL.pdf adresinden erişildi.

Sylva, K., Sammons, P., Melhuish, E., Siraj, I. ve Taggart, B. (2020). Developing 21st century skills in early childhood: The contribution of process quality to self-regulation and pro-social behaviour. Zeıtschrift Fur 
Erzlehungswıssenschaft, 23, 465-484. https://doi.org/10.1007/s11618-020-00945-x

Tuğluk, M. N. ve Özkan, B. (2019) MEB 2013 Okul öncesi eğitim programının 21. yüzyıl becerileri açısından analizi. Temel Ĕ̆gitim Dergisi, 1(4), 29-38.

Van Laar, E., Van Deursen, A. J., Van Dijk, J. A. ve De Haan, J. (2017). The relation between 21st-century skills and digital skills: A systematic literature review. Computers in Human Behavior, 72, 577-588. https://doi.org/10.1016/j.chb.2017.03.010

Voogt, J. ve Roblin, N. P. (2010). 21st century skills discussion paper. University of Twente. 10 Ocak 2021 tarihinde https://www.voced.edu.au/content/ngv:56611adresinden erişildi.

Voogt, J. ve Roblin, N. P. (2012). A comparative analysis of international frameworks for 21st century competences: Implications for national curriculum policies. Journal of Curriculum Studies, 44(3), 299-321.

Wiggins, G. (1998). A true test: Toward more authentic and equitable assessment. Phi Delta Kappan, 70(9). 703713.

Windschitl, M. (2002). Framing constructivism in practice as the negotiation of dilemmas: An analysis of the conceptual, pedagogical, cultural, and political challenges facing teachers. Review of Educational Research, 72(2), 131-175.

Wortham, S. C. ve Hardin, B. J. (2016). Assessment in early childhood education. Upper Saddle River, N.J.: Pearson

Yıldırım, A. ve Şimşek, H. (2013). Sosyal bilimlerde nitel araştırma yöntemleri. (9. bs.). Ankara: Seçkin Yayıncılık.

Zajda, J. (2015). Globalisation and its impact on education and policy. J. Zajda (Ed.) Second international handbook on globalisation, education and policy research (s. 105-125) içinde. Dordrecht: Springer. 


\section{EXTENDED ABSTRACT}

\section{Introduction}

Globalization, transnational economic, environmental, and political challenges along with the rapid development of information and communication technologies are continuously transforming the skills and knowledge individuals need for success (e.g., Chu et al., 2017; Griffin et al., 2012; Saavedra \& Opfer, 2012a; Zajda, 2015). Mastery of the traditional basic skills (3Rs- reading, writing, and arithmetic) is no longer enough. Instead, individuals need a greater ability to respond flexibly to complex problems, communicate effectively, produce new knowledge, work in teams, and be resilient in the face of rapid change for successful work, citizenship, and life in the 21st century (Ananiadou \& Claro, 2009; P21-A Network of Battelle for Kids, 2019a). These abilities are often referred to as 21st century skills and competencies.

With the aim of strengthening understanding towards 21st century skills, many frameworks (e.g., Assessment and Teaching of 21st Century Skills-ATC21S, Partnership for 21st century skills-P21 etc.) have been drawn up under the support of international organizations, governments, and consulting firms, which indicates that there is a strong interest in describing of the skills that are regarded as important for the 21st century context. These frameworks provide valuable insight into the specifications of the types of objectives, teaching, learning, and assessment approaches associated with the implementation of 21st century skills in school curricula. Therefore, from the perspective of sustainable curriculum development, analysis of how these frameworks inform curriculum policies and educational practices across various countries is vital in order to better understand what the curricular integration of 21st century skills requires from teachers, schools and educational systems.

Accordingly, the present study aims to critically examine the salience of 21st century skills in MoNE 2013 early childhood education curriculum (curriculum booklet and curriculum activity book). Guiding questions of the study are formulated as follows:

1. Which 21st century skills are distinguished in the curriculum booklet?

2. Does the curriculum booklet address specific learning objectives for the implementation of 21st century skills?

3. Which 21st century skills are distinguished in the curriculum activity book?

Addressing these questions is important for two reasons. First, future learners need an excellent start in early learning if they are to cope with mid to late 21st century challenges. Thus, 21st century skills learning must start very early in life, especially during early childhood education. Second, children may not learn these skills if they are not provided with the right type of experiences. For an effective way of learning 21st century skills, they need to be explicitly and clearly emphasized in early childhood education curriculum. Hence, a critical review of curricular integration of 21st century skills may contribute to the better understanding of how the national curriculum policies be actively involved in the 21st century initiatives and the development of early childhood education curricula.

\section{Method}

In the present study, document analysis, a form of qualitative research, was adopted. Document analysis is a systematic procedure for reviewing or evaluating documents-both printed and electronic material (Bowen, 2009). Document used for systematic evaluation as part of this study was MoNE 2013 early childhood education curriculum (curriculum booklet and activity book). Descriptive analysis (Yıldırım \& Şimşek, 2013) was used to examine and organize the data contained in the documents. Specifically, all developmental characteristics, learning objectives, and indicators towards five developmental domains; information related to planning and practice of early childhood education (learning centers and activity types), and assessment of early childhood education (assessment of children, assessment of program, and self-assessment of the teacher) in the curriculum booklet and exemplary activities in the curriculum activity book constituted the units of descriptive analysis. They were analyzed to ascertain the presence or absence of 21st century skills based on 
the 21st Century Skills Early Learning Framework (P21 ELF), which was particularly developed to encourage educators, providers of services to young children, administrators, and policymakers to include early learning as they develop strategies for full integration of 21st century skills into their learning programs.

\section{Results}

The results of the study showed that with respect to 21st century skills, MoNE 2013 early childhood curriculum booklet provided support for learning and innovation skills and life and career skills with some exceptions, including creativity and innovation, collaboration, flexibility and adaptability, productivity and accountability etc. Specifically, the curriculum booklet mostly included communication, critical thinking and problem solving skills, out of learning and innovation skills. Among life and career skills, initiative and selfdirection and social and cross-cultural skills were the most addressed skills. On the other hand, information, media and technology skills were not adequately addressed in the curriculum booklet. The results of the study also revealed that in the curriculum booklet, there were learning objectives and indicators mostly for critical thinking and problem solving, initiative and self-direction skills. Intriguingly, there were no learning objectives and indicators for collaboration as well as information, media, and technology skills. Moreover, the results of the study indicated that the curriculum activity book mostly contained activities for critical thinking and problem solving and communication skills. There were a limited number of activities addressing flexibility and adaptability, initiative and self-direction skills, leadership and responsibility and social and cross-cultural skills. There were no activities for information, media, and technology skills.

\section{Conclusion and Recommendations}

Based on the results of the present study, MoNE 2013 early childhood curriculum (curriculum booklet and activity book) has the potential to support implementation of 21st century skills for early childhood. Especially, the curriculum offers sufficient guidance in the way of implementation of 21st century skills, including critical thinking and problem solving, communication, initiative and self-direction skills. Nevertheless, the curriculum needs to be revised in order to include 21st century skills in a balanced way. Furthermore, the curriculum should demonstrate an acknowledgement and support for information, media, and technology skills. 